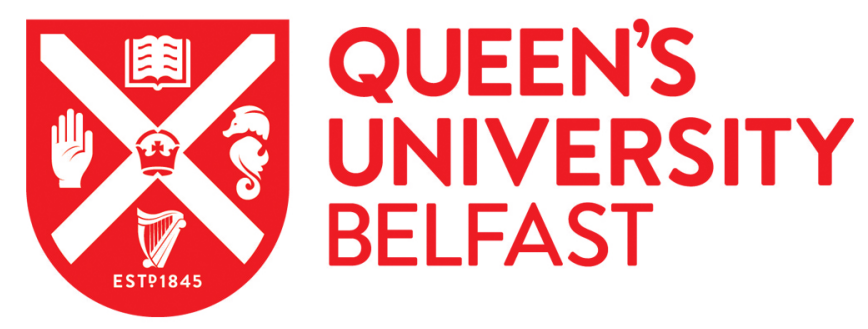

\title{
Behavioural incentive interventions for health behaviour change in young people (5-18years old): A systematic review and meta-analysis
}

Corepal, R., Tully, M. A., Kee, F., Miller, S., \& Hunter, R. F. (2018). Behavioural incentive interventions for health behaviour change in young people (5-18years old): A systematic review and meta-analysis. Preventive Medicine, 110, 55-66. https://doi.org/10.1016/j.ypmed.2018.02.004

Published in:

Preventive Medicine

Document Version:

Peer reviewed version

Queen's University Belfast - Research Portal:

Link to publication record in Queen's University Belfast Research Portal

Publisher rights

(C) 2018 Published by Elsevier Inc

This manuscript version is made available under the CC-BY-NC-ND 4.0 license http://creativecommons.org/licenses/by-nc-nd/4.0/,which permits distribution and reproduction for noncommercial purposes, provided the author and source are cited.

\section{General rights}

Copyright for the publications made accessible via the Queen's University Belfast Research Portal is retained by the author(s) and / or other copyright owners and it is a condition of accessing these publications that users recognise and abide by the legal requirements associated with these rights.

Take down policy

The Research Portal is Queen's institutional repository that provides access to Queen's research output. Every effort has been made to ensure that content in the Research Portal does not infringe any person's rights, or applicable UK laws. If you discover content in the Research Portal that you believe breaches copyright or violates any law, please contact openaccess@qub.ac.uk. 


\section{Accepted Manuscript}

Behavioural incentive interventions for health behaviour change in young people (5-18 years old): A systematic review and metaanalysis

Rekesh Corepal, Mark A. Tully, Frank Kee, Sarah Miller, Ruth F. Hunter

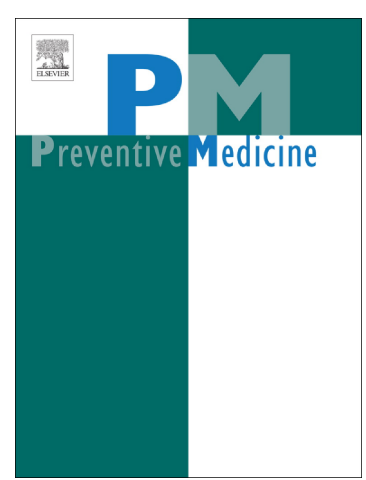

PII: S0091-7435(18)30033-1

DOI: https://doi.org/10.1016/j.ypmed.2018.02.004

Reference: YPMED 5301

To appear in:

Preventive Medicine

Received date:

3 July 2017

Revised date:

1 February 2018

Accepted date:

5 February 2018

Please cite this article as: Rekesh Corepal, Mark A. Tully, Frank Kee, Sarah Miller, Ruth F. Hunter, Behavioural incentive interventions for health behaviour change in young people (5-18 years old): A systematic review and meta-analysis. The address for the corresponding author was captured as affiliation for all authors. Please check if appropriate. Ypmed(2017), https://doi.org/10.1016/j.ypmed.2018.02.004

This is a PDF file of an unedited manuscript that has been accepted for publication. As a service to our customers we are providing this early version of the manuscript. The manuscript will undergo copyediting, typesetting, and review of the resulting proof before it is published in its final form. Please note that during the production process errors may be discovered which could affect the content, and all legal disclaimers that apply to the journal pertain. 
Behavioural incentive interventions for health behaviour change in young people (5-18 years old): A systematic review and meta-analysis

Rekesh Corepal $^{\text {a.b }}$, Mark A Tully ${ }^{\text {a,b }}$, Frank Kee ${ }^{\text {a,b }}$, Sarah Miller ${ }^{\text {b,c }}$, Ruth F Hunter ${ }^{\text {a,b }}$

${ }^{a}$ Centre for Public Health, Queen's University Belfast, Northern Ireland, UK

${ }^{b}$ UKCRC Centre of Excellence for Public Health Research (NI), Queen's University Belfast, Northern Ireland, UK

${ }^{\mathrm{c}}$ School of Education, Queen's University Belfast, Northern Ireland, UK

Corresponding author(s): Rekesh Corepal/Ruth Hunter, UKCRC Centre of Excellence for Public Health Research (NI), Queen's University Belfast, Northern Ireland, UK; Email: rcorepal01@qub.ac.uk; ruth.hunter@qub.ac.uk

Main text word count: 4185

Abstract word count: 235 


\begin{abstract}
Physical inactivity, an unhealthy diet, smoking, and alcohol consumption are key determinants of morbidity and mortality. These health behaviours often begin at a young age and track into adulthood, emphasising a need for interventions in children and young people. Previous research has demonstrated the potential effectiveness of behavioural incentive (BI) interventions in adults. However, little is known about their effectiveness in children and adolescents.

Eight bibliographic databases were searched. Eligibility criteria included controlled trials using behavioural incentives (rewards provided contingent on successful performance of the target behaviour) as an intervention component for health behaviour change in children and adolescents. Intervention effects (standardised mean differences or odds ratios) were calculated and pooled by health behaviour, using a random effects model.

Twenty-two studies were included (of $n=8,392$ identified), 19 of which were eligible for meta-analysis: physical activity $(n=8)$; healthier eating $(n=3)$; and smoking $(n=8)$. There was strong evidence that behavioural incentives may encourage healthier eating behaviours, some evidence that behavioural incentives were effective for encouraging physical activity behaviour, and limited evidence to support the use of behavioural incentives for smoking cessation and prevention in adolescents.

Findings suggest that behavioural incentives may encourage uptake and initiation of healthy eating and physical activity in young people. However, this is a limited evidence base and a wide range of incentive designs have yet to be explored. Future research should further investigate the acceptability of these intervention approaches for young people.
\end{abstract}

\title{
Keywords
}

Incentives; Child; Adolescent; Physical Activity; Smoking; Diet; Behaviour; Meta-analysis 


\section{Introduction}

Many unhealthy lifestyle behaviours in youth, such as physical inactivity, an unhealthy diet, smoking, and alcohol consumption, track into adulthood, and are key determinants of morbidity and mortality. Childhood and adolescence is also an important time to shape habitual lifestyle behaviours (Kelder et al., 1994). Therefore, reducing these modifiable risk factors is a major public health priority, necessitating innovative approaches.

Behavioural incentives (BIs) are an example of such an innovative approach for health behaviour change. Using BIs involves explicitly informing participants that future rewards, or removal of future punishments, will be contingent on performance of the health behaviour (Michie et al., 2013). The use of BIs has its foundations in operant conditioning (Skinner, 1938). Operant conditioning posits that behaviours are affected by their consequences (Staddon and Cerutti, 2003). In operant conditioning theory, BIs can be used as a stimulus to reinforce and increase future occurrences of the behaviour (Skinner, 1953). Reinforcements can be positive (e.g. presenting a BI on completion of the behaviour), or negative (e.g. removing a BI when the behaviour is not performed). Further definitions and examples of key terms used in this paper are shown in Appendix A.

Recent evidence suggests BIs may be effective at encouraging health-related behaviour change (Giles et al., 2014; Mantzari et al., 2015). Although the reviews by Giles et al. (2014) and Mantzari et al. (2015) have shown potential short term benefits of using BIs, these studies focused solely on adults, and only used financial incentives. A systematic review on the use of BIs in those aged 11-19 years found BIs may be effective for non-complex health behaviours (e.g. attendance for vaccination; attendance for screening), but the effectiveness for complex health behaviours such as smoking, alcohol intake, dietary change or physical activity, remains unclear (Kavanagh et al., 2011). However, the review by Kavanagh et al. (2011) only included studies where BIs were the sole component or in combination with only one other intervention component. Consequently, common approaches involving complex multi-component interventions (including an incentive explicitly linked to the achievement of the target behaviour) remains unexplored. The review by Kavanagh et al. (2015) focused on young people aged 11-19 years old, suggesting that there is a gap in the literature exploring the effectiveness of BI interventions for children. Incentives given in this context may be washed out by what goes on in the home environment where parental and/or sibling modelling and support may counteract or attenuate gains the child makes on a given day or over time.

Further, the evidence justifying interventions using BIs for maintenance of behaviour change is inconclusive (Giles et al., 2014; Kavanagh et al., 2011; Mantzari et al., 2015; Mitchell et al., 2013). 
Although a meta-analysis suggests that extrinsic rewards can undermine intrinsic motivation, the majority of included studies are laboratory-based, dealing with artificial choices and their relevance to real world health behaviours is unknown (Deci et al., 1999).Nevertheless, BIs may be important for the initiation of health-related behaviours, and be supportive for maintaining behaviours that require self-control, such as smoking cessation and reduced calorie consumption (Promberger and Marteau, 2013).

To address these evidence gaps, the aim of the current systematic review and meta-analysis was to investigate the effectiveness of controlled trials using BI interventions for encouraging physical activity, diet, alcohol, or smoking behaviour change in young people (5-18 year olds). Further objectives included investigating the effectiveness of BIs for maintenance of behaviour change, and the effects of different intervention lengths, follow-ups, incentive designs, and behaviour change techniques (BCTs) used.

\section{Methods}

\section{Eligibility criteria}

The following eligibility criteria was defined a priori:

Participants: A non-clinical population of children and adolescents (mean age between 5-18 years old) were included. Populations with diagnosed diseases/conditions (e.g. diabetes, cancer) were excluded.

Study Design: All controlled trials (e.g. randomised controlled trials (RCTs), cluster RCTs, pre-post controlled trials) were included. Included studies compared the use of a BI-based intervention to promote health behaviour change versus a control or comparison group such as no intervention, usual treatment, or the same treatment without a BI component.

Intervention: Interventions incorporating BIs (i.e. material incentives, self-incentives; and non-material incentives such as social incentives and non-specific incentives) were included (Michie et al., 2013; see Appendix A for definitions). Interventions in which participants were initially unaware of the potential for a reward, or rewards were not contingent on effort and/or progress in performing the behaviour were excluded.

Outcome Measure(s): Studies involving a measure of health behaviour change (physical activity, healthier eating, alcohol, and smoking) using validated measures were included. A measure was considered valid if it was specifically stated in the article that the measure was valid (and supported by relevant references for the target population) or if the authors could identify at least one appropriate study that provided evidence of the validity of the instrument for measuring health behaviour for the target population. 


\section{Search strategy}

Eight electronic databases (Medline, Embase, CINAHL Plus, PsycINFO, Cochrane Central Register of Controlled Trials (CENTRAL), EconLit, Business Source Premier, and Education Resources Information Centre (ERIC) were searched from date of inception until November 2016. Reference lists of included studies, and review articles were hand searched to identify other relevant studies. Search terms included type of health behaviour, type of incentive, study design, and children and adolescents (see Appendix B). Only studies in English were included. Two researchers (RC and RH) undertook independent screening of titles and abstracts, and full texts for eligibility. Any disagreements regarding inclusion of studies were resolved by consensus. Percentage agreement and Cohen's Kappa were calculated for title/abstract and full text screening.

\section{Data extraction}

Extracted data included: study design, participant characteristics, description of the interventions(s) and control group, follow up periods, outcome measures, and results of the intervention.

The domain framework for financial incentives (Adams et al., 2014) was applied to describe the incentive interventions and modified to include non-financial incentives; BCTs were classified using Michie et al's 93-item taxonomy (Michie et al., 2013). RC and RH independently assessed the risk of bias using the Cochrane Collaboration's tool (Higgins et al., 2011).

\section{Evidence synthesis}

Extracted study characteristics, intervention designs, outcomes of the study, BCTs and incentive domains were summarised in tabular form and described. Studies were synthesised per targeted health behaviour. Short-term effects were those $<6$ months, and maintained intervention effects were defined as $\geq 6$ months (Prochaska and DiClemente, 1983).

Meta-analyses using a random effects model were conducted using Review Manager (Revman [Computer program]. Version 5.3.5. Copenhagen: The Nordic Cochrane Centre, The Cochrane Collaboration, 2014). Meta-analyses were undertaken by health behaviour if analyses of at least two similar interventions/comparisons could be performed (Valentine et al., 2011) and relevant data available. Standardised mean differences (SMD) using final value scores and Hedges g were used as the measure of effect size for continuous data, and odds ratios (OR) for dichotomous data. Heterogeneity was measured by the $\mathrm{I}^{2}$ statistic (Higgins et al., 2003). Studies were described as providing strong evidence if at least $80 \%$ of included studies demonstrated a significant intervention effect; promising evidence if 50-79\%; 
some evidence if $\leq 49 \%$; no evidence if none of the included studies demonstrated a significant intervention effect; and, lack of evidence if there were no identified studies in the pre-defined category (Hunter et al, 2015).

BCT (behaviour change technique) frequency was analysed, and BCT effectiveness measured using the method described in Hynynen et al. (2016). Effect sizes were calculated for each study. Effective BCTs were defined as those that were present in $50 \%$ of the effective interventions (significant intervention effect ( $p<.05)$ versus comparison group) but not at all present, or present in only one of the non-effective trials. BCT effectiveness was presented as an effectiveness ratio, calculated as the ratio of the number of times a BCT was present in an effective intervention compared to the number of times it was present as a component of all interventions (Hynynen et al, 2016).

\section{Results}

\section{Protocol and registration}

The study protocol was registered with PROSPERO (CRD42015024468) and reported following the PRISMA guidelines (Liberati et al., 2009).

\section{Study selection}

The search strategy identified 8392 records; 22 studies were included in the review, and 19 studies in the meta-analysis (see Appendix C). Percentage agreement between researchers $(90.8 \%)$ and inter-rater agreement for title/abstract and full-text screening (Cohen's Kappa $=0.79$ ) was good. Table 1 presents a summary of study characteristics; Appendix D reports the interventions by type of incentive design. 
In total, 24,560 participants (50\% female, $22 \%$ ethnic minority population) were included in all studies; 6,960 participants were children with an average age of $\leq 12$ years. The median sample size was 261 participants, median intervention duration was 42 days and a median follow-up period was 210 days across all included studies. Eight studies focused on increasing physical activity; six on increasing consumption of fruit, vegetables, and fruit juice (FVJ); and eight on reducing smoking. No alcohol-related studies met the eligibility criteria.

\section{Physical activity}

There was some evidence of the effectiveness of BIs for physical activity behaviour change with two of eight studies demonstrating significant intervention effects; one in the short-term (Goldfield et al., 2006) ( $\leq 6$ months from baseline), and one study showing a maintained effect (Finkelstein et al., 2013).

Finkelstein et al. (2013) awarded toy store vouchers (worth $\sim$ 19 USD) when pedometer goals were met, in addition to the chance to win other prizes with a value of $\sim \$ 74$ USD (e.g. tickets to the zoo) via monthly lotteries. Goldfield et al. (2006) incentivised physical activity with access to television; accruing approximately sixty minutes of physical activity equated to sixty minutes of television access.

Six studies showed no significant intervention effect of BIs for physical activity behaviour change. One study used academic BIs of four points added to the participant's nine week grade if a three-week fitness challenge was fully completed (Brinker, 2008). Two studies used the Fit 'n' Fun Dudes intervention, consisting of peer modelling, pedometer step goals, and BIs (Hardman et al., 2011; Horne et al., 2009a). Material BIs such as balls, erasers, and Frisbees were awarded for meeting daily step count. One Fit ' $n$ ' Fun Dudes study showed a significant intervention effect for girls; however, when pooled with boys (Figure 1), the significant intervention effect was reduced (Horne et al., 2009a). A pedometer class competition to incentivise physical activity was used in another study (Suchert et al., 2015); classes with the most steps were awarded, and those with the largest increase in steps were awarded cash prizes ( $\sim 3477$ USD in total). There was a significant increase from baseline for the intervention group for selfreported MVPA and active commuting at post-intervention, although not when final values were compared with the comparison group (Figure 1). Two studies incentivised physical activity by using access to television as a reward (Roemmich et al., 2004; Roemmich et al., 2012). Although there was a significant difference in MVPA with the intervention group (Roemmich et al., 2012) this was not significant at follow up, nor when compared with the comparison group (Figure 1). 
The meta-analysis (Figure 1) detected small, non-significant, positive intervention effects (SMD 0.31; $95 \%$ CI -0.27 to $0.88 ; n=1834)$ with a high level of heterogeneity $\left(I^{2}=95 \% ; p<0.001\right)$. A sensitivity analysis related to type of BIs used was performed. Only two studies incorporated financial incentives (Finkelstein et al., 2013; Suchert et al., 2015). The six studies using non-financial incentives (Brinker, 2008; Goldfield et al., 2006; Hardman et al., 2011; Horne et al., 2009a; Roemmich et al., 2004; Roemmich et al., 2012) found small, non-significant positive intervention effects (SMD 0.11; 95\% CI 0.26 to $0.48 ; \mathrm{N}=438$ ) with a decreased $\mathrm{I}^{2}$ of $63 \%(\mathrm{p}=0.02)$ (Figure 2$)$.

\section{Healthier Eating}

There was strong evidence for the effectiveness of BIs to encourage young people to increase FVJ consumption with 5 out of 6 studies demonstrating a significant intervention effect; three in the short-term (Baranowski et al., 2002; Horne et al., 2004; Presti et al., 2015), and two showing a maintained effect (Horne et al., 2009b; Morrill et al., 2016). One study recruited participants from African American boy scout troops (Baranowski et al., 2002). The scout troops received lessons, and tasks to complete at home with the goal to increase availability and accessibility of FJV at home, increase preferences for vegetables, and learn simple recipes. Scouts were given weekly goals and if these goals were achieved the participants received BIs worth $\sim \$ 1$ USD at the next meeting. If all dietary goals were met, scouts received a 5-a-Day achievement badge. Four studies using the 'Food Dudes' intervention resulted in a positive intervention effect (Horne et al., 2009b; Horne et al., 2004; Morrill et al., 2016; Presti et al., 2015). Interventions were comprised of peer modelling, goal setting, self-monitoring, and material BIs such as customised 'Food Dudes' stationery, certificates and stickers. Two 'Food Dude' studies investigated intervention effects by sub-groups; age (5 to 7 years) (Horne et al., 2004) and weight (overweight or non-overweight using BMI) (Presti et al., 2015). Results showed significantly greater consumption of FVJ at follow-up for intervention participants for both studies. Two 'Food Dude' studies evaluated the maintained effect of the intervention, and found a significant positive intervention effect at 10 months (Morrill et al., 2016), and 12 months (Horne et al., 2009b) for lunchbox consumed fruit and vegetables. A further study found no significant intervention effect for lunchtime consumption of fruit and vegetables provided by schools (Upton et al., 2013). There was significant change in fruit and vegetable consumption in the intervention schools at three months post-baseline but this was not maintained at 12 months.

Three studies (3/6 studies) were included in the meta-analysis (Baranowski et al., 2002; Horne et al., 2009b; Morrill et al., 2016) shown in Figure 3. Results showed large significant positive intervention 
effect (SMD 1.12; 95\% CI 0.19 to 2.05; $\mathrm{n}=1717$ ) with a high level of heterogeneity $\mathrm{I}^{2}$ of $98 \%$ ( $\left.\mathrm{p}=0.01\right)$. A sensitivity analysis related to methodology and target population was performed (Figure 4). Results of this meta-analysis showed a significant positive intervention effect (SMD 0.45; 95\% CI 0.35 to 0.55 ) with a decreased $\mathrm{I}^{2}$ of $0 \%(\mathrm{p}=0.42)$. However, findings from both should be interpreted with caution due to the small number of studies.

\section{Smoking}

There was limited evidence for the effectiveness of BIs to reduce smoking in young people. One study (1 out of 8 studies) showed a significant intervention effect in the short term (12 weeks) (Krishnan-Sarin et al., 2006). The intervention used an incentive design comprised of material incentives in the form of cash. Payments to participants would increase after each consecutive negative breath sample, but this was reset to the original level if a sample was above the threshold for determining abstinence or participants failed to provide a sample. Participants were required to visit the laboratory for breath tests to verify abstinence.

Other smoking interventions did not show a significant intervention effect ( 7 out of 8 studies). All participants were aged 13-18 years. Five of these studies tested smoke free class competitions (SFCC) format (Crone et al., 2003; Isensee et al., 2012; Schulze et al., 2006; Vartiainen et al., 1996; Wiborg and Hanewinkel, 2002); with $90 \%$ to remain abstinent by intervention end in order to enter a lottery/draw for a chance to win various prizes for their class. Two studies used cash (payments increased for each subsequent breath test showing abstinence) and a reset contingency (if a participant's abstinence could not be verified, payment was reset to the initial level) (Krishnan-Sarin et al., 2013; Reynolds et al., 2015).

The meta-analysis adjusted for clustering at the school level by inflating standard errors (Higgins and Green, 2008), and using an intra-class correlation coefficient (ICC) of 0.097 obtained from Siddiqui (Siddiqui et al., 1996). Where only the number of classes at follow up were available, estimated number of schools was derived as shown in a recent Cochrane review (Johnston et al., 2012) (classes/school ratio of 5:2). The meta-analysis of all studies (Figure 5) demonstrated small statistically significant intervention effects for reducing smoking with a low level of heterogeneity (OR 0.80; 95\% CI 0.65, $0.98\left(\mathrm{I}^{2}=0 \%\right.$; $\mathrm{p}=0.51 ; \mathrm{n}=8881)$. Five studies using SFCC demonstrated no statistically significant intervention effects for reducing smoking with a low level of heterogeneity (OR $0.83 ; 95 \% \mathrm{CI} 0.67,1.03 ; \mathrm{I}^{2}=0 \% ; \mathrm{p}=0.87$; $=$ 8750). Material incentives comprised of only financial payments found large effects in favour of BIs but this was not statistically significant with moderate heterogeneity, OR 0.29; 95\% CI 0.06, $1.42\left(\mathrm{I}^{2}=41 \%\right.$; $\mathrm{p}=0.18 ; \mathrm{n}=131)$. Studies using financial incentives verified abstinence using an objective measure of smoking status whereas studies involving competition used self-report smoking measures. 


\section{Behaviour Change Techniques (BCTs)}

\section{Frequency of BCTs}

Figure 6 details the frequency of employed BCTs. Material incentives and material rewards were the most commonly used ( $n=17)$, followed by non-specific incentives (use of a class competition $(n=6)$; academic incentives $(n=1)$; and access to television $(n=4)$. Most studies also provided social support in the form of encouragement, advice, or non-contingent praise $(n=15)$; goal setting to achieve a predefined outcome $(n=14)$; feedback on the outcome of behaviour $(n=14)$; and opportunities to self-monitor behaviour $(n=13)$.

\section{Effectiveness of BCTs}

Effective BCTs were defined as those that were present in 50\% of the effective interventions (significant intervention effect $(p<.05)$ versus comparison group) but not at all present, or present in only one of the non-effective trials. Result of the analyses showed no distinct patterns of BCTs meeting these criteria (See Appendix E). Although no BCTs were deemed effective per these definitions, the most common BCTs were 'adding objects to the environment' and 'self-monitoring of behavior' (ratio of BCTs present in effective studies divided by the number of times the BCT is present in all studies, shown in Appendix E). Heterogeneity in study design, range of BCTs used in the multi-component interventions, and the small number of included studies may explain the lack of a clear pattern for effective BCTs. This makes it difficult to disentangle the effective components, which indeed may not be appropriate given the interplay and interaction between BCTs (i.e. these are not discrete entities/components acting in isolation). In addition, assumptions were made that BCTs contained in the intervention description are successfully implemented, which of course may not have been the case; therefore, these results should be interpreted with caution.

\section{Risk of bias}

Overall, the risk of bias for each domain was low or unclear in most areas in most studies (See Appendix F). Random sequence generation, allocation concealment, and incomplete outcome data were the main potential sources of bias. As $22.7 \%$ of studies (5/22 studies) were deemed to be of high risk of bias, caution is necessary with interpretation of findings. Moreover, 63.6\% of studies (14/22 studies) were deemed to be of unclear risk of bias, suggesting the need for improved reporting of intervention methods.

\section{Discussion}


Findings from this review show that BIs may be effective for encouraging behaviour change for particular health behaviours in young people. Studies showed some evidence that providing money or access to television could be effective for encouraging physical activity. There was strong evidence to support the use of valued objects such as achievement badges and customised 'Food Dude' incentives for increasing FVJ consumption, and limited evidence to support the use of incentives for smoking cessation and prevention in adolescents. All included studies investigating physical activity and dietary behaviour were conducted with pre-adolescents, and all included studies focusing on smoking were with adolescents.

The evidence for the effectiveness of incentive-based interventions for maintained health behaviour change in young people is largely inconclusive. Maintained behaviour change could be possible if BIs are in place for a sufficient period of time to create habits (Oliver and Brown, 2012), yet the appropriate length of time is unclear. It has been proposed that people do not always act in the way that they want, so BIs could provide motivation to behave in a way that accurately represents their long-term goals, enhancing autonomy (Kimmel and Troxel, 2012; Marteau et al., 2009; Paloyo et al., 2015), and eliminating social pressures from peers' potentially negative reactions (Wolff, 2014). Consequently, what is intrinsically desired can be attempted under the guise of an extrinsic motivator (Kifmann, 2014). Complex interventions such as these have multiple strands operating at several levels and this needs to be further explored to allow the identification of assumed pathways of change and to help uncover the balance between extrinsic and intrinsic motivation in effecting change. Two possible mechanisms are: a) behaviour may be habitual by the time incentives are withdrawn (as per the automaticity work of Bargh (1992)); and/or b) participants are satisfied with the benefits of the behaviour change (e.g. feel better), and so wish to maintain it to continue to receive these benefits (as per Rothman's theory of maintenance (Rothman et al., 2011)). Alternatively, it may be that for incentives to work optimally, persons in the home environment - who are ultimately responsible - for the child's welfare also need to be able to earn incentives for appropriate/desirable behaviour.

\section{Effectiveness of material incentives}

All four studies using material incentives of a financial nature demonstrated a greater intervention effect when compared to the control. (Finkelstein et al., 2013; Krishnan-Sarin et al., 2013; Krishnan-Sarin et al., 2006; Reynolds et al., 2015).

Other non-financial incentives (i.e. material incentives with a low financial value, social incentives, and non-specific incentives such as access to television), were on a whole, no more effective for reducing smoking or increasing physical activity than the comparison group. Yet, a similar intervention to that used in two physical activity studies (Hardman et al., 2011; Horne et al., 2009a) was found to be effective for 
increasing FJV consumption at school (Horne et al., 2009b; Horne et al., 2004; Morrill et al., 2016; Presti et al., 2015). Perhaps, the goal of increasing FJV consumption is easier to achieve than increasing physical activity; so, the health behaviour rather than the form of BI may play a bigger role here. The 'Food Dude' interventions measured FJV at snack time and lunchtime in schools, with participants receiving immediate rewards if successful. Meeting physical activity goals as set in the 'Fit n Fun Dudes' interventions is more complex and would require more time.

\section{Effectiveness of competition}

The findings of this review are in line with a previous Cochrane review (Johnston et al., 2012) which did not demonstrate evidence to support the use of SFCC for smoking prevention. In contrast, two metaanalyses found SFCC to be effective in young people. However, these studies had certain limitations such as the inclusion of only two studies (Kavanagh et al., 2011), and not adjusting for clustering (Isensee and Hanewinkel, 2012). There are also some concerns about class competitions fostering an atmosphere of dishonesty, suspicion (Etter and Bouvier, 2006; Kairouz et al., 2009) and bullying, although other studies have not found negative peer pressure or bullying (Hanewinkel et al., 2010). Given the strong peer influence among adolescents, interventions at the class, year group or whole of school level that provides a supportive social environment may be a key element to motivate behaviour change (Silva et al., 2014).

\section{Ethics and acceptability}

Research on the issue of acceptability conducted by Giles et al. (2015) found that participants (adults) thought financial BIs were unfair by rewarding 'bad behaviour'. There were concerns that people may begin the unhealthy behaviour to receive financial incentives when they stop. Further, interventions incorporating BIs raise particular ethical implications such as "perceived bribery, coercion, and paternalism," thus undermining the autonomy of the individual (Marteau et al., 2009). Currently, there is no consensus whether BIs are ethically sound and acceptable (Oliver et al., 2009), particularly for young people, though research is lacking.

\section{Limitations}

Strengths of the review include searching a range of bibliographic databases from different disciplines, and in-depth exploration of effective BCTs. Due to the small number of studies, small sample sizes in several studies, heterogeneity, and variable quality of studies, results should be interpreted with caution.

\section{Future research}


Health behaviours examined here are 'complex' (Kane et al., 2004) with numerous and varied determinants, and the effectiveness of BIs to affect behaviour change could be influenced by a variety of factors (Lynagh et al., 2013), and work via different mechanisms (Boyce et al., 2008). Variability shown in intervention designs and BCTs used in studies, shows that there is not a 'one size fits all approach'. Questions regarding BIs such as 'who do they work for?', 'how do they work?' and 'is it acceptable and appropriate to use them?' require further investigation.

Using competition as a BI in complex public health interventions in young people is still a relatively under-investigated area. Disentangling the various 'active ingredients' in competition-based interventions to better understand distinct mechanisms of action are needed. Habit formation is complex (Gardner, 2015), likely with different mechanisms at play for building 'good' habits, and removing 'bad' habits. In particular, longer interventions, interventions with a tapered withdrawal of BIs, or incorporating on-going behavioural support (Sigmon and Patrick, 2012) could lead to maintained behaviour change (Lynagh et al., 2014).

\section{Conclusion}

The findings from this review show promising evidence that BIs may be effective for encouraging physical activity behaviour change and healthy eating in young people. However, this is a limited evidence base and a wide range of incentive designs have yet to be explored. 


\section{Acknowledgements}

The work was undertaken under the auspices of the UKCRC Centre of Excellence for Public Health Research Northern Ireland. UKCRC Public Health Research Centres of Excellence which are funded by the British Heart Foundation, Cancer Research UK, Economic and Social Research Council, Medical Research Council, the National Institute for Health Research, and the Wellcome Trust. RC is supported by a PhD studentship funded by the Department for the Economy (DfE). RH is supported by a NIHR Career Development Fellowship from the National Institute of Health Research (NIHR) and acknowledges funding support from the HSC Research and Development Division. 


\section{References}

Adams, J., Giles, E.L., McColl, E., Sniehotta, F.F., 2014. Carrots, sticks and health behaviours: a framework for documenting the complexity of financial incentive interventions to change health behaviours. Health psychology review 8:286-95.

Baranowski, T., Baranowski, J., Cullen, K.W., deMoor, C., Rittenberry, L., Hebert, D., Jones, L., 2002. 5 a day Achievement Badge for African-American Boy Scouts: pilot outcome results. Prev Med $34: 353-63$.

Bargh, J.A., 1992. The ecology of automaticity: toward establishing the conditions needed to produce automatic processing effects. Am J Psychol 105:181-99.

Boyce, T., Robertson, R., Dixon, A., 2008. Commissioning and behaviour change: Kicking bad habits. The King's Fund, London.

Brinker, J.S., 2008. Academic incentives impact on increasing seventh-graders physical activity during leisure time. Walden University, USA.

Crone, M.R., Reijneveld, S.A., Willemsen, M.C., van Leerdam, F.J., Spruijt, R.D., Sing, R.A., 2003. Prevention of smoking in adolescents with lower education: a school based intervention study. J Epidemiol Community Health 57:675-80.

Deci, E.L., Koestner, R., Ryan, R.M., 1999. A meta-analytic review of experiments examining the effects of extrinsic rewards on intrinsic motivation. Psychol Bull 125:627-68; discussion 92-700.

Etter, J.F., Bouvier, P., 2006. Some doubts about one of the largest smoking prevention programmes in Europe, the smokefree class competition. J Epidemiol Community Health 60:757-9.

Finkelstein, E.A., Tan, Y.T., Malhotra, R., Lee, C.F., Goh, S.S., Saw, S.M., 2013. A cluster randomized controlled trial of an incentive-based outdoor physical activity program. J Pediatr 163:167-72.e1.

Gardner, B., 2015. A review and analysis of the use of 'habit' in understanding, predicting and influencing health-related behaviour. Health psychology review 9:277-95.

Giles, E.L., Robalino, S., McColl, E., Sniehotta, F.F., Adams, J., 2014. The effectiveness of financial incentives for health behaviour change: systematic review and meta-analysis. PLoS One 9:e90347.

Giles, E.L., Robalino, S., Sniehotta, F.F., Adams, J., McColl, E., 2015. Acceptability of financial incentives for encouraging uptake of healthy behaviours: A critical review using systematic methods. Prev Med 73:145-58.

Goldfield, G.S., Mallory, R., Parker, T., Cunningham, T., Legg, C., Lumb, A., Parker, K., Prud'homme, D., Gaboury, I., et al., 2006. Effects of open-loop feedback on physical activity and television viewing in overweight and obese children: a randomized, controlled trial. Pediatrics 118:e157-66.

Hanewinkel, R., Isensee, B., Maruska, K., Sargent, J.D., Morgenstern, M., 2010. Denormalising smoking in the classroom: does it cause bullying? J Epidemiol Community Health 64:202-8.

Hardman, C.A., Horne, P.J., Fergus Lowe, C., 2011. Effects of rewards, peer-modelling and pedometer targets on children's physical activity: a school-based intervention study. Psychology \& health 26:3-21. 
Higgins, J.P., Altman, D.G., Gotzsche, P.C., Juni, P., Moher, D., Oxman, A.D., Savovic, J., Schulz, K.F., Weeks, L., et al., 2011. The Cochrane Collaboration's tool for assessing risk of bias in randomised trials. BMJ (Clinical research ed.) 343:d5928.

Higgins, J.P., Green, S., 2008. Cochrane handbook for systematic reviews of interventions. Wiley, Sussex.

Higgins, J.P., Thompson, S.G., Deeks, J.J., Altman, D.G., 2003. Measuring inconsistency in metaanalyses. BMJ (Clinical research ed.) 327:557-60.

Horne, P.J., Hardman, C.A., Lowe, C.F., Rowlands, A.V., 2009a. Increasing children's physical activity: a peer modelling, rewards and pedometer-based intervention. Eur J Clin Nutr 63:191-8.

Horne, P.J., Hardman, C.A., Lowe, C.F., Tapper, K., Le Noury, J., Madden, P., Patel, P., Doody, M., 2009b. Increasing parental provision and children's consumption of lunchbox fruit and vegetables in Ireland: the Food Dudes intervention. Eur J Clin Nutr 63:613-8.

Horne, P.J., Tapper, K., Lowe, C.F., Hardman, C.A., Jackson, M.C., Woolner, J., 2004. Increasing children's fruit and vegetable consumption: a peer-modelling and rewards-based intervention. Eur J Clin Nutr 58:1649-60.

Hunter, R.F., Christian, H., Veitch, J., Astell-Burt, T., Hipp, J.A., Schipperijn, J., 2015. The impact of interventions to promote physical activity in urban green space: a systematic review and recommendations for future research. Soc Sci Med 124:246-56.

Hynynen, S.T., van Stralen, M.M., Sniehotta, F.F., Araujo-Soares, V., Hardeman, W., Chinapaw, M.J., Vasankari, T., Hankonen, N., 2016. A systematic review of school-based interventions targeting physical activity and sedentary behaviour among older adolescents. International review of sport and exercise psychology 9:22-44.

Isensee, B., Hanewinkel, R., 2012. Meta-analysis on the effects of the smoke-free class competition on smoking prevention in adolescents. Eur Addict Res 18:110-5.

Isensee, B., Morgenstern, M., Stoolmiller, M., Maruska, K., Sargent, J.D., Hanewinkel, R., 2012. Effects of Smokefree Class Competition 1 year after the end of intervention: a cluster randomised controlled trial. J Epidemiol Community Health 66:334-41.

Johnston, V., Liberato, S., Thomas, D., 2012. Incentives for preventing smoking in children and adolescents. Cochrane Database Syst Rev 10:CD008645.

Kairouz, S., O'Loughlin, J., Lague, J., 2009. Adverse effects of a social contract smoking prevention program among children in Quebec, Canada. Tobacco control 18:474-8.

Kane, R.L., Johnson, P.E., Town, R.J., Butler, M., 2004. A structured review of the effect of economic incentives on consumers' preventive behavior. Am J Prev Med 27:327-52.

Kavanagh, J., Oakley, A., Harden, A., Trouton, A., Powell, C., 2011. Are incentive schemes effective in changing young people's behaviour? A systematic review. Health Education Journal 70:192-205.

Kelder, S.H., Perry, C.L., Klepp, K.I., Lytle, L.L., 1994. Longitudinal tracking of adolescent smoking, physical activity, and food choice behaviors. Am J Public Health. 1994 84:1121-6.

Kifmann, M., 2014. Comment on 'Paying People to Act in Their Own Interests: Incentives versus Rationalisation in Public Health’by Jonathan Wolff. Public Health Ethics:phu038. 
Kimmel, S.E., Troxel, A.B., 2012. Novel incentive-based approaches to adherence. Clinical trials (London, England) 9:689-95.

Krishnan-Sarin, S., Cavallo, D.A., Cooney, J.L., Schepis, T.S., Kong, G., Liss, T.B., Liss, A.K., McMahon, T.J., Nich, C., et al., 2013. An exploratory randomized controlled trial of a novel highschool-based smoking cessation intervention for adolescent smokers using abstinence-contingent incentives and cognitive behavioral therapy. Drug Alcohol Depend 132:346-51.

Krishnan-Sarin, S., Duhig, A.M., McKee, S.A., McMahon, T.J., Liss, T., McFetridge, A., Cavallo, D.A., 2006. Contingency management for smoking cessation in adolescent smokers. Exp Clin Psychopharmacol 14:306-10.

Liberati, A., Altman, D.G., Tetzlaff, J., Mulrow, C., Gotzsche, P.C., Ioannidis, J.P., Clarke, M., Devereaux, P.J., Kleijnen, J., et al., 2009. The PRISMA statement for reporting systematic reviews and meta-analyses of studies that evaluate health care interventions: explanation and elaboration. Journal of clinical epidemiology 62:e1-34

Lynagh, M.C., Sanson-Fisher, R.W., Bonevski, B., 2013. What's good for the goose is good for the gander. Guiding principles for the use of financial incentives in health behaviour change. International journal of behavioral medicine 20:114-20.

Lynagh, M.C., Sanson-Fisher, R.W., Bonevski, B., 2014. Keeping the 'Goose' on the Menu: Response to Commentaries on Financial Incentives in Health Behaviour Change. International journal of behavioral medicine 21:206-09.

Mantzari, E., Vogt, F., Shemilt, I., Wei, Y., Higgins, J.P., Marteau, T.M., 2015. Personal financial incentives for changing habitual health-related behaviors: A systematic review and meta-analysis. Prev Med 75:75-85.

Marteau, T.M., Ashcroft, R.E., Oliver, A., 2009. Using financial incentives to achieve healthy behaviour. BMJ (Clinical research ed.) 338:b1415.

Michie, S., Richardson, M., Johnston, M., Abraham, C., Francis, J., Hardeman, W., Eccles, M.P., Cane, J., Wood, C.E., 2013. The behavior change technique taxonomy (v1) of 93 hierarchically clustered techniques: building an international consensus for the reporting of behavior change interventions. Ann Behav Med 46:81-95.

Mitchell, M.S., Goodman, J.M., Alter, D.A., John, L.K., Oh, P.I., Pakosh, M.T., Faulkner, G.E., 2013. Financial incentives for exercise adherence in adults: systematic review and meta-analysis. Am J Prev Med 45:658-67.

Morrill, B.A., Madden, G.J., Wengreen, H.J., Fargo, J.D., Aguilar, S.S., 2016. A Randomized Controlled Trial of the Food Dudes Program: Tangible Rewards are More Effective Than Social Rewards for Increasing Short- and Long-Term Fruit and Vegetable Consumption. J Acad Nutr Diet 116:618-29.

Oliver, A., Brown, L.D., 2012. A consideration of user financial incentives to address health inequalities. Journal of health politics, policy and law 37:201-26.

Oliver, A., Marteau, T.M., Ashcroft, R.E., 2009. Can financial carrots improve health? Journal of health services research \& policy 14:1-2.

Paloyo, A.R., Reichert, A.R., Reuss-Borst, M., Tauchmann, H., 2015. Who responds to financial incentives for weight loss? Evidence from a randomized controlled trial. Social science \& medicine (1982) 145:44-52. 
Presti, G., Cau, S., Oppo, A., Moderato, P., 2015. Increased Classroom Consumption of HomeProvided Fruits and Vegetables for Normal and Overweight Children: Results of the Food Dudes Program in Italy. J Nutr Educ Behav 47:338-44.

Prochaska, J.O., DiClemente, C.C., 1983. Stages and processes of self-change of smoking: toward an integrative model of change. J Consult Clin Psychol 51:390-5.

Promberger, M., Marteau, T.M., 2013. When do financial incentives reduce intrinsic motivation? comparing behaviors studied in psychological and economic literatures. Health psychology : official journal of the Division of Health Psychology, American Psychological Association 32:950-7.

Reynolds, B., Harris, M., Slone, S.A., Shelton, B.J., Dallery, J., Stoops, W., Lewis, R., 2015. A feasibility study of home-based contingency management with adolescent smokers of rural Appalachia. Exp Clin Psychopharmacol 23:486-93.

Roemmich, J.N., Gurgol, C.M., Epstein, L.H., 2004. Open-loop feedback increases physical activity of youth. Medicine and science in sports and exercise 36:668-73.

Roemmich, J.N., Lobarinas, C.L., Barkley, J.E., White, T.M., Paluch, R., Epstein, L.H., 2012. Use of an open-loop system to increase physical activity. Pediatr Exerc Sci 24:384-98.

Rothman, A.J., Baldwin, A.S., Hertel, A.W., Fuglestad, P.T., 2011. Self-regulation and behavior change: disentangling behavioral initiation and behavioral maintenance, in: Vohs, K.D., Baumeister, R.F. (Eds.), Handbook of self-regulation: Research, theory, \& applications. Guildford Press, New York, pp. 106-22.

Ryan, R.M., Deci, E.L., 2017. Self-determination theory: Basic psychological needs in motivation, development, and wellness. Guilford Publications.

Schulze, A., Mons, U., Edler, L., Potschke-Langer, M., 2006. Lack of sustainable prevention effect of the "Smoke-Free Class Competition" on German pupils. Prev Med 42:33-9.

Siddiqui, O., Hedeker, D., Flay, B.R., Hu, F.B., 1996. Intraclass correlation estimates in a schoolbased smoking prevention study. Outcome and mediating variables, by sex and ethnicity. Am J Epidemiol 144:425-33.

Sigmon, S.C., Patrick, M.E., 2012. The use of financial incentives in promoting smoking cessation. Prev Med 55 Suppl:S24-32.

Silva, M.N., Marques, M.M., Teixeira, P.J., 2014. Testing theory in practice: The example of selfdetermination theory-based interventions. Eur Health Psychol 16:171-80.

Skinner, B.F., 1938. The behaviour of organisms: An experimental analysis. Appleton-Century.

Skinner, B.F., 1953. Science and human behavior. Simon and Schuster.

Staddon, J.E., Cerutti, D.T., 2003. Operant conditioning. Annu Rev Psychol 54:115-44.

Suchert, V., Isensee, B., Sargent, J., Weisser, B., Hanewinkel, R., Group, 1.S., 2015. Prospective effects of pedometer use and class competitions on physical activity in youth: A cluster-randomized controlled trial. Prev Med 81:399-404.

Upton, D., Upton, P., Taylor, C., 2013. Increasing children's lunchtime consumption of fruit and vegetables: an evaluation of the Food Dudes programme. Public Health Nutr 16:1066-72. 
Valentine, J.C., Pigott, T.D., Rothstein, H.R., 2011. How many studies do you need? A primer on statistical power for meta-analysis. Quality control and applied statistics 56:117-20.

Vartiainen, E., Saukko, A., Paavola, M., Vertio, H., 1996. 'No Smoking Class' competitions in Finland: their value in delaying the onset of smoking in adolescence. Health Promotion International 11:189-92.

Wiborg, G., Hanewinkel, R., 2002. Effectiveness of the "Smoke-Free Class Competition" in delaying the onset of smoking in adolescence. Prev Med 35:241-9.

Wolff, J., 2014. Paying people to act in their own interests: incentives versus rationalization in public health. Public Health Ethics:phu035. 
Figure 1. Forest plot of behavioural incentive interventions for physical activity (SMD)

Figure 2. Forest plot of non-financial incentive interventions for physical activity (SMD)

Figure 3. Forest plot of behavioural incentive interventions for 'healthier eating' (SMD)

Figure 4. Forest plot of only 'Food Dude' incentive interventions for 'healthier eating' (SMD)

Figure 5. Forest plot of behavioural incentive interventions for reducing smoking (OR)

Figure 6. Frequency of behaviour change techniques in all studies (in descending order) 
Table 1: Characteristics of included studies included in the systematic review

\begin{tabular}{|c|c|c|c|c|c|c|c|}
\hline & $\begin{array}{l}\text { Baseline } \\
\text { Participant } \\
\text { Characterist } \\
\text { ics }\end{array}$ & $\begin{array}{l}\text { Interventi } \\
\text { on Group }\end{array}$ & $\begin{array}{l}\text { Comparis } \\
\text { on Group }\end{array}$ & $\begin{array}{l}\text { Follow } \\
\text { up } \\
\text { (Post- } \\
\text { baselin } \\
\text { e) }\end{array}$ & Outcome & $\begin{array}{l}\text { Results } \\
\text { (Furthest } \\
\text { follow up) }\end{array}$ & $\begin{array}{l}\text { Risk of } \\
\text { Bias } \\
\text { Summa } \\
\text { ry }\end{array}$ \\
\hline \multicolumn{8}{|c|}{ Target Behaviour: Physical Activity } \\
\hline $\begin{array}{l}\text { Brinker } \\
\text { (2008) } \\
\text { Country: } \\
\text { USA } \\
\text { Study } \\
\text { design: } \\
\text { Controlle } \\
\text { d trial }\end{array}$ & $\begin{array}{l}\mathrm{N}=24 \\
\text { Age range } \\
\text { 12-14 years } \\
\% \text { female } \\
\text { unavailable; } \\
\% \text { ethnicity } \\
\text { unavailable } \\
\text { School } \\
\text { setting }\end{array}$ & $\begin{array}{l}\mathrm{N}=13 \\
\text { Duration: } \\
3 \text { weeks } \\
\text { Academic } \\
\text { points (4 } \\
\text { points } \\
\text { added to } \\
\text { their 9- } \\
\text { week } \\
\text { grade) }\end{array}$ & $\begin{array}{l}\mathrm{N}=11 \\
\text { No } \\
\text { interventio } \\
\mathrm{n}\end{array}$ & $\begin{array}{l}3 \\
\text { weeks }\end{array}$ & $\begin{array}{l}\text { Number of } \\
\text { days/week } \\
\text { did at least } \\
60 \text { mins } \\
\text { MVPA }\end{array}$ & $\begin{array}{l}\text { Interventio } \\
\text { n group: } \\
\text { Mean 5.8 } \\
\text { (SD 1.6) } \\
\text { Compariso } \\
\text { n group: } \\
\text { Mean 6.0 } \\
\text { (SD 1.3) }\end{array}$ & $\begin{array}{l}\text { High } \\
\text { risk }\end{array}$ \\
\hline $\begin{array}{l}\text { Finkelstei } \\
\text { n et al } \\
\text { (2013) } \\
\text { Country: } \\
\text { Singapore } \\
\text { Study } \\
\text { design: } \\
\text { RCT }\end{array}$ & $\begin{array}{l}\mathrm{N}=285 \\
\text { Mean age } \\
8.2 \text { (SD } \\
1.5) ; 46 \% \\
\text { female; } \\
86.3 \% \\
\text { Chinese } \\
\text { Home and } \\
\text { community } \\
\text { setting }\end{array}$ & $\begin{array}{l}\text { N=145 } \\
\text { Duration: } \\
9 \text { months } \\
\text { Toy store } \\
\text { vouchers, } \\
\text { and prizes } \\
\text { such as } \\
\text { entrance to } \\
\text { a zoo }\end{array}$ & $\begin{array}{l}\mathrm{N}=89 \\
\text { Usual } \\
\text { activities }\end{array}$ & $\begin{array}{l}9 \\
\text { months }\end{array}$ & $\begin{array}{l}\text { Pedometer } \\
\text { step count } \\
\text { over } \\
\text { weekdays }\end{array}$ & $\begin{array}{l}\text { Interventio } \\
\text { n group: } \\
\text { Mean } \\
8660 \text { (SD } \\
567)\end{array}$ & $\begin{array}{l}\text { Low } \\
\text { risk }\end{array}$ \\
\hline $\begin{array}{l}\text { Goldfield } \\
\text { et al } \\
\text { (2006) } \\
\text { Country: } \\
\text { Canada } \\
\text { Study } \\
\text { design: } \\
\text { RCT }\end{array}$ & $\begin{array}{l}\mathrm{N}=30 \\
\text { Mean age } \\
10.4 \text { (SD } \\
1.3) ; 56.6 \% \\
\text { female; } \% \\
\text { ethnicity } \\
\text { unavailable; } \\
\text { all } \\
\text { participants } \\
\text { BMI above }\end{array}$ & $\begin{array}{l}\mathrm{N}=14 \\
\text { Duration: } \\
8 \text { weeks } \\
\text { Feedback } \\
\text { and } \\
\text { reinforced } \\
\text { for PA } \\
\text { with } \\
\text { access to }\end{array}$ & $\begin{array}{l}\mathrm{N}=16 \\
\text { Feedback } \\
\text { on PA. No } \\
\text { contingenc } \\
\text { y for } \\
\text { access to } \\
\text { TV }\end{array}$ & $\begin{array}{l}8 \\
\text { weeks }\end{array}$ & $\begin{array}{l}\text { Accelerome } \\
\text { ter } \\
\text { determined } \\
\text { MVPA } \\
\text { (daily } \\
\text { minutes of } \\
\text { MVPA) }\end{array}$ & $\begin{array}{l}\text { Interventio } \\
\mathrm{n} \text { group: } \\
\text { Mean 22.5 } \\
\text { [SE 3.5] }\end{array}$ & $\begin{array}{l}\text { Unclear } \\
\text { risk }\end{array}$ \\
\hline
\end{tabular}




\begin{tabular}{|c|c|c|c|c|c|c|c|}
\hline & $\begin{array}{l}85 \text { th } \\
\text { percentile } \\
\text { Home } \\
\text { setting }\end{array}$ & $\mathrm{TV}$ & & & & & \\
\hline $\begin{array}{l}\text { Hardman } \\
\text { et al } \\
\text { (2011) } \\
\text { Country: } \\
\text { Wales, } \\
\text { UK } \\
\text { Study } \\
\text { design: } \\
\text { Cluster } \\
\text { RCT }\end{array}$ & $\begin{array}{l}\mathrm{N}=236 \\
\text { Mean age } \\
9.1 \text { (SD } \\
1.3) ; 55.5 \% \\
\text { female; \% } \\
\text { ethnicity } \\
\text { unavailable } \\
\text { School } \\
\text { setting }\end{array}$ & $\begin{array}{l}\mathrm{N}=118 \\
\text { Duration: } \\
12 \text { school } \\
\text { days. } \\
\text { Followed } \\
\text { by taper } \\
\text { phase of } \\
14 \text { weeks } \\
\text { (incentives } \\
\text { stopped, } \\
\text { but still } \\
\text { had } \\
\text { pedometer } \\
\text { s and diary } \\
\text { to self- } \\
\text { record step } \\
\text { counts. } \\
\text { Occasional } \\
\text { letters and } \\
\text { certificates } \\
\text { provided) } \\
\text { Fit 'n' Fun } \\
\text { Dudes } \\
\text { Programm } \\
\text { e: Peer } \\
\text { modelling, } \\
\text { goal- } \\
\text { setting, } \\
\text { and } \\
\text { incentives }\end{array}$ & $\begin{array}{l}\mathrm{N}=67 \\
\text { No } \\
\text { rewards } \\
\text { interventio } \\
\mathrm{n} \\
\mathrm{N}=51 \text { No } \\
\text { interventio } \\
\mathrm{n}\end{array}$ & $\begin{array}{l}13 / 14 \\
\text { weeks }\end{array}$ & $\begin{array}{l}\text { Pedometer } \\
\text { step count } \\
\text { over } 8 \\
\text { school days }\end{array}$ & $\begin{array}{l}\text { Interventio } \\
\text { n group: } \\
\text { Mean } \\
13085 \text { (SD } \\
3058) \\
\text { Compariso } \\
\text { n group: } \\
\text { Mean } \\
13939 \text { (SD } \\
3672 \text { ) }\end{array}$ & $\begin{array}{l}\text { Unclear } \\
\text { risk }\end{array}$ \\
\hline $\begin{array}{l}\text { Horne et } \\
\text { al (2009a) } \\
\text { Country: } \\
\text { Wales, } \\
\text { UK } \\
\text { Study } \\
\text { design: } \\
\text { Cluster }\end{array}$ & $\begin{array}{l}\mathrm{N}=89 \\
\text { Mean age } \\
10.0 \text { (SD } \\
0.7) ; 51.7 \% \\
\text { female; \% } \\
\text { ethnicity } \\
\text { unavailable } \\
\text { School }\end{array}$ & $\begin{array}{l}\mathrm{N}=38 \\
\text { Duration: } \\
8 \text { school } \\
\text { days (12 } \\
\text { weeks } \\
\text { maintenan } \\
\text { ce) } \\
\text { Followed }\end{array}$ & $\begin{array}{l}\mathrm{N}=51 \\
\text { No } \\
\text { interventio } \\
\mathrm{n}\end{array}$ & $\begin{array}{l}15 / 16 \\
\text { weeks }\end{array}$ & $\begin{array}{l}\text { Pedometer } \\
\text { step count } \\
\text { over } 8 \\
\text { school days }\end{array}$ & $\begin{array}{l}\text { Interventio } \\
\text { n group: } \\
\text { Mean } \\
\text { 14218 (SD } \\
4031 \text { ) } \\
\\
\text { Compariso } \\
\text { n group: }\end{array}$ & $\begin{array}{l}\text { Unclear } \\
\text { risk }\end{array}$ \\
\hline
\end{tabular}




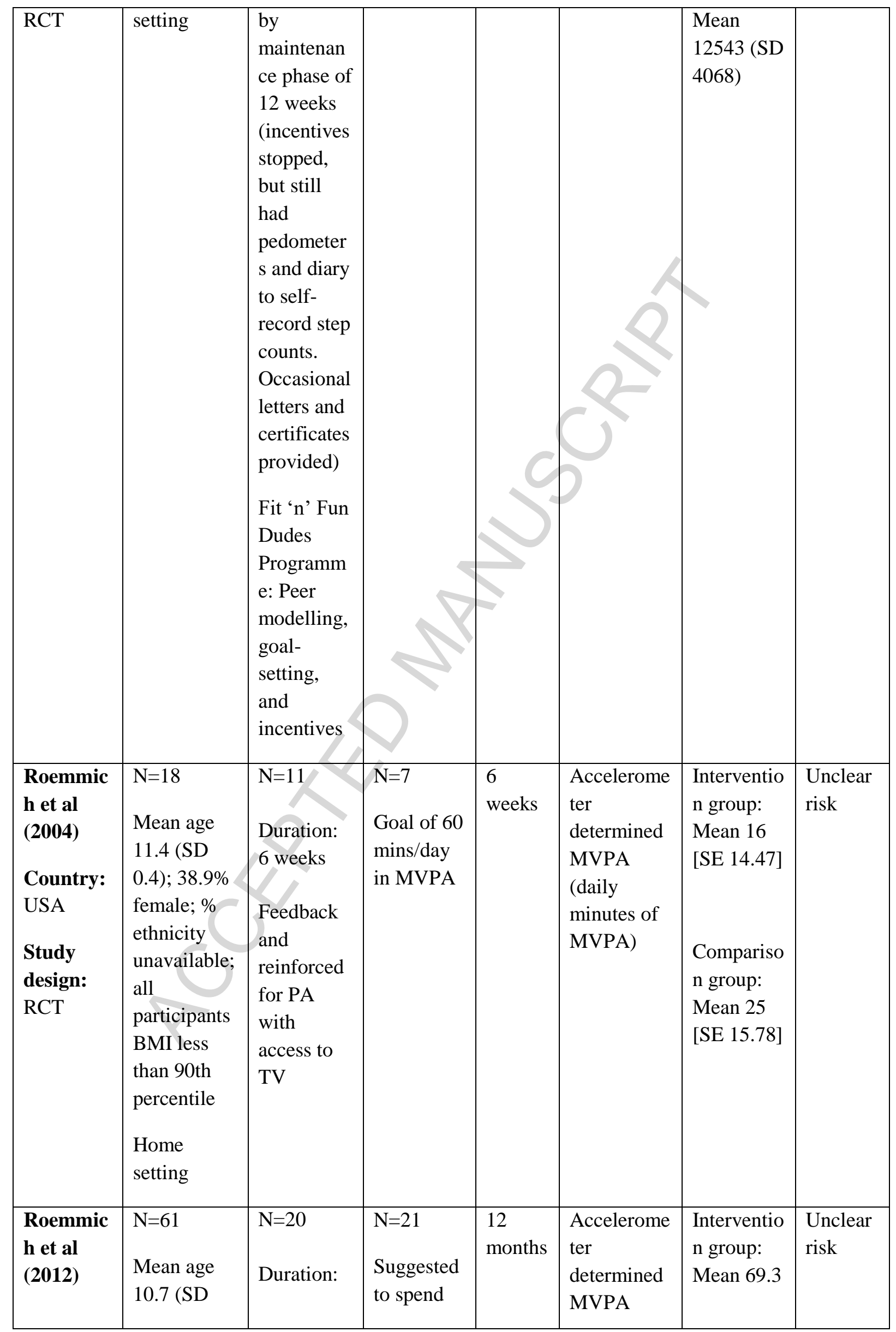




\begin{tabular}{|c|c|c|c|c|c|c|c|}
\hline $\begin{array}{l}\text { Country: } \\
\text { USA } \\
\text { Study } \\
\text { design: } \\
\text { RCT }\end{array}$ & $\begin{array}{l}1,6) ; 49.2 \% \\
\text { female; \% } \\
\text { ethnicity } \\
\text { unavailable; } \\
\text { all } \\
\text { participants } \\
\text { BMI } \\
\text { between } \\
\text { 85th and } \\
\text { 3rd } \\
\text { percentiles } \\
\text { Home } \\
\text { setting }\end{array}$ & $\begin{array}{l}4 \text { months } \\
\text { Feedback } \\
\text { and } \\
\text { reinforced } \\
\text { for PA } \\
\text { with } \\
\text { access to } \\
\text { TV }\end{array}$ & $\begin{array}{l}60 \\
\text { mins/day } \\
\text { in MVPA }\end{array}$ & & $\begin{array}{l}\text { (daily } \\
\text { minutes of } \\
\text { MVPA) }\end{array}$ & $\begin{array}{l}\text { [SE 0.6] } \\
\text { Compariso } \\
\text { n group: } \\
\text { Mean 68.6 } \\
\text { [SE 7.3] }\end{array}$ & \\
\hline $\begin{array}{l}\text { Suchert } \\
\text { et al } \\
(\mathbf{2 0 1 5}) \\
\text { Country: } \\
\text { Germany } \\
\text { Study } \\
\text { design: } \\
\text { Cluster } \\
\text { RCT }\end{array}$ & $\begin{array}{l}\mathrm{N}=1162 \\
\text { Mean age } \\
13.7 \text { (SD } \\
0.7) ; 48.2 \% \\
\text { female; \% } \\
\text { ethnicity } \\
\text { unavailable } \\
\text { School } \\
\text { setting }\end{array}$ & $\begin{array}{l}\mathrm{N}=702 \\
\text { Duration: } \\
12 \text { weeks } \\
\text { (Mar-May } \\
2014 \text { ) } \\
\text { Class step } \\
\text { competitio } \\
\text { n with } \\
\text { opportunit } \\
\text { y to win } \\
\text { class } \\
\text { prizes }\end{array}$ & $\begin{array}{l}\mathrm{N}=460 \\
\text { Usual } \\
\text { education }\end{array}$ & $\begin{array}{l}5 \\
\text { months } \\
\text { (Jun/Ju } \\
12014) \\
\text { (as } \\
\text { soon as } \\
\text { possibl } \\
\text { e post- } \\
\text { test) }\end{array}$ & $\begin{array}{l}\text { Self- } \\
\text { reported } \\
\text { days/week } \\
\text { with } 60 \\
\text { mins } \\
\text { MVPA }\end{array}$ & $\begin{array}{l}\text { Interventio } \\
\text { n group: } \\
\text { Mean 4.4 } \\
\text { (SD 0.1) }\end{array}$ & $\begin{array}{l}\text { Unclear } \\
\text { risk }\end{array}$ \\
\hline \multicolumn{8}{|c|}{ Target Behaviour: Healthier Eating } \\
\hline $\begin{array}{l}\text { Baranow } \\
\text { ski et al } \\
\text { (2002) } \\
\text { Country: } \\
\text { USA } \\
\text { Study } \\
\text { design: } \\
\text { Randomis } \\
\text { ed cluster } \\
\text { controlled } \\
\text { trial }\end{array}$ & $\begin{array}{l}\mathrm{N}=134 \\
\text { Mean age } \\
10.0 \text { (SD } \\
6.4) ; 91 \% \\
\text { African- } \\
\text { American; } \\
\text { Home and } \\
\text { community } \\
\text { setting }\end{array}$ & $\begin{array}{l}\mathrm{N}=75 \\
\text { Duration: } \\
8 \text { weeks } \\
5 \text { a Day } \\
\text { Achievem } \\
\text { ent Badge } \\
\text { Programm } \\
\text { e: } \\
\text { Education, } \\
\text { recipe } \\
\text { preparatio } \\
\mathrm{n}, \\
\text { practicing } \\
\text { skills, and } \\
\text { incentives }\end{array}$ & $\begin{array}{l}\mathrm{N}=59 \\
\text { No } \\
\text { interventio } \\
\mathrm{n}\end{array}$ & $\begin{array}{l}8 \\
\text { weeks }\end{array}$ & $\begin{array}{l}\text { Fruit, juice, } \\
\text { and } \\
\text { vegetables } \\
\text { (servings a } \\
\text { day) }\end{array}$ & $\begin{array}{l}\text { Interventio } \\
\text { n group: } \\
\text { Mean 3.6 } \\
\text { (SD 0.3) } \\
\\
\text { Compariso } \\
\text { n group: } \\
\text { Mean 2.8 } \\
\text { (SD 0.3) }\end{array}$ & $\begin{array}{l}\text { Unclear } \\
\text { risk }\end{array}$ \\
\hline
\end{tabular}




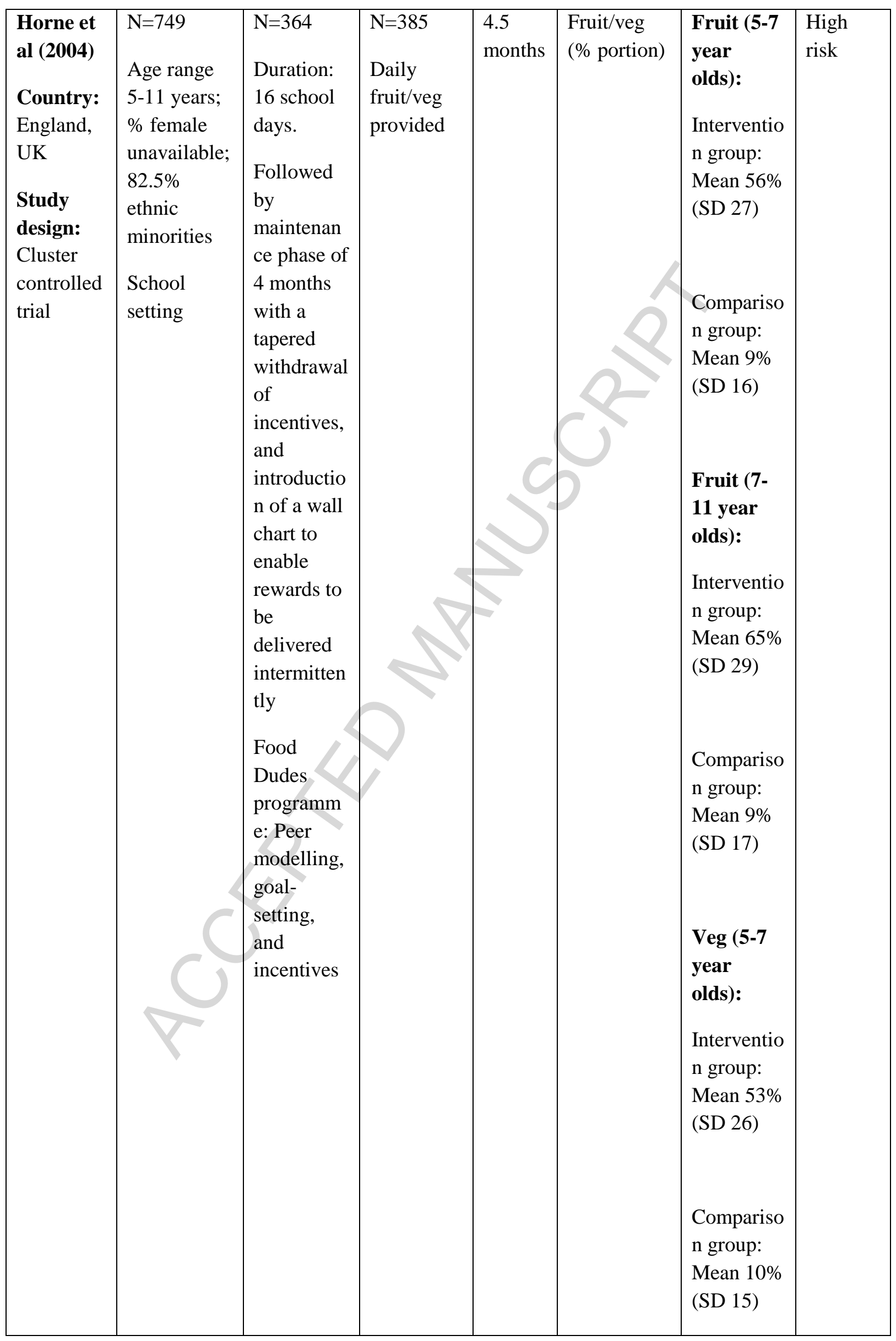




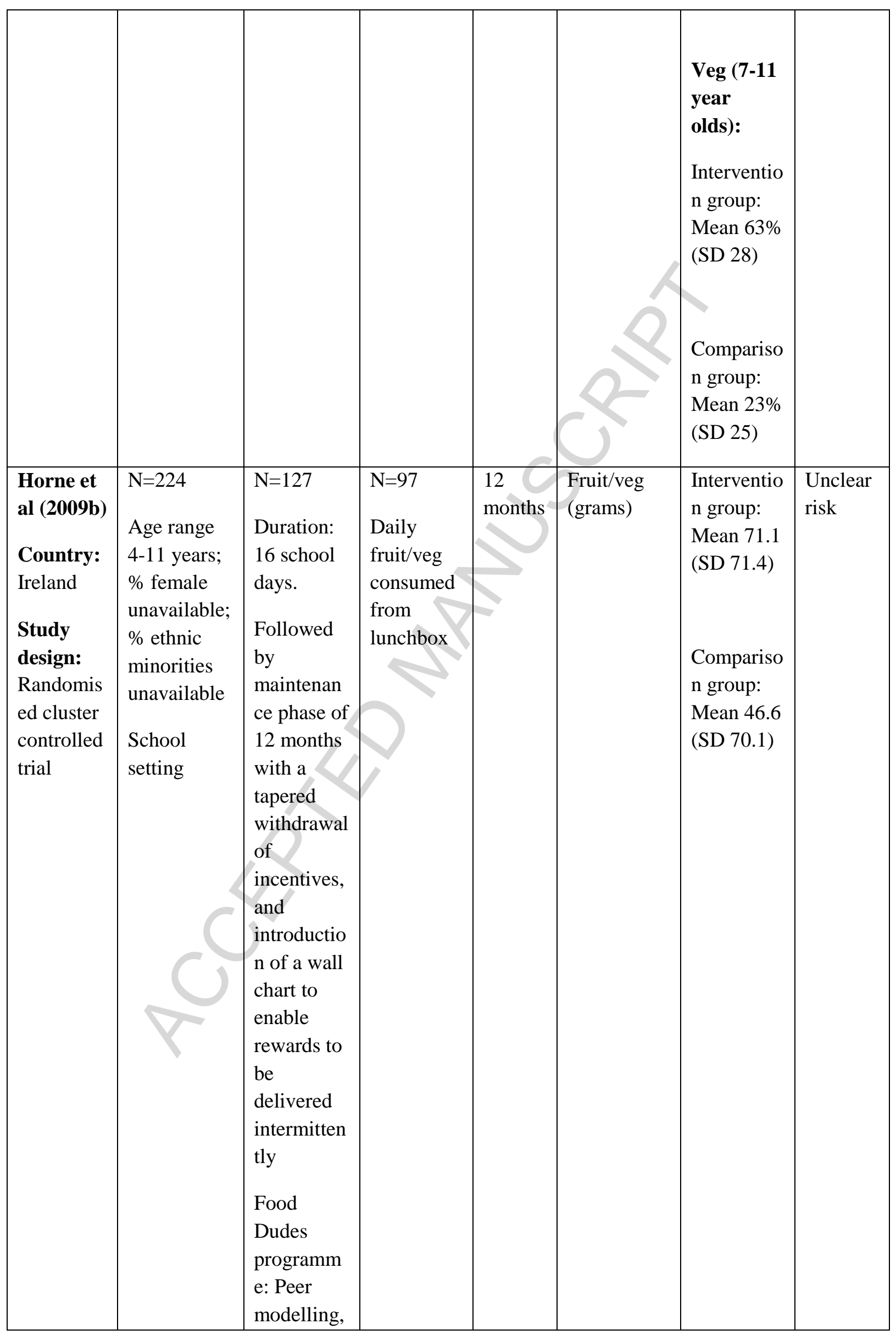




\begin{tabular}{|c|c|c|c|c|c|c|c|}
\hline & & $\begin{array}{l}\text { goal- } \\
\text { setting, } \\
\text { and } \\
\text { incentives }\end{array}$ & & & & & \\
\hline $\begin{array}{l}\text { Morrill et } \\
\text { al (2016) } \\
\text { Country: } \\
\text { USA } \\
\text { Study } \\
\text { design: } \\
\text { Randomis } \\
\text { ed cluster } \\
\text { controlled } \\
\text { trial }\end{array}$ & $\begin{array}{l}\mathrm{N}=2292 \\
\text { Children in } \\
\text { grades 1-5; } \\
45.9 \% \\
\text { female; } \\
91 \% \text { White } \\
\text { School } \\
\text { setting }\end{array}$ & $\begin{array}{l}\text { N=671 } \\
\text { Duration: } \\
16 \text { days. } \\
\text { Followed } \\
\text { by } \\
\text { maintenan } \\
\text { ce phase } \\
10 \text { weeks } \\
\text { with a } \\
\text { tapered } \\
\text { withdrawal } \\
\text { of } \\
\text { incentives, } \\
\text { and } \\
\text { introductio } \\
\text { n of a wall } \\
\text { chart to } \\
\text { enable } \\
\text { rewards to } \\
\text { be } \\
\text { delivered } \\
\text { intermitten } \\
\text { tly } \\
\text { Food } \\
\text { Dudes } \\
\text { programm } \\
\text { e: Peer } \\
\text { modelling, } \\
\text { goal- } \\
\text { setting, } \\
\text { and } \\
\text { incentives }\end{array}$ & $\begin{array}{l}\mathrm{N}=668 \\
\text { No } \\
\text { interventio } \\
\mathrm{n} \\
\text {. }\end{array}$ & $\begin{array}{l}10.5 \\
\text { months }\end{array}$ & $\begin{array}{l}\text { Fruit/veg } \\
\text { (cups) }\end{array}$ & $\begin{array}{l}\text { Interventio } \\
\mathrm{n} \text { group: } \\
\text { Mean 0.4 } \\
\text { [SE 0.0] } \\
\\
\text { Compariso } \\
\text { n group: } \\
\text { Mean 0.3 } \\
\text { [SE 0.0] }\end{array}$ & $\begin{array}{l}\text { Unclear } \\
\text { risk }\end{array}$ \\
\hline $\begin{array}{l}\text { Presti et } \\
\text { al (2015) } \\
\text { Country: } \\
\text { Italy } \\
\text { Study } \\
\text { design: } \\
\text { Cluster }\end{array}$ & $\begin{array}{l}\mathrm{N}=409 \\
\text { Age range } \\
5-11 \text { years; } \\
50.6 \text { female; } \\
\% \text { ethnic } \\
\text { minorities } \\
\text { unavailable }\end{array}$ & $\begin{array}{l}\mathrm{N}=230 \\
\text { Duration: } \\
16 \text { school } \\
\text { days. } \\
\text { Followed } \\
\text { by a }\end{array}$ & $\begin{array}{l}\mathrm{N}=164 \\
\text { Daily } \\
\text { fruit/veg } \\
\text { provided }\end{array}$ & $\begin{array}{l}12 \\
\text { months }\end{array}$ & $\begin{array}{l}\text { Fruit/veg } \\
\text { (grams) }\end{array}$ & $\begin{array}{l}\text { Overweig } \\
\text { ht group: } \\
\text { Interventio } \\
\text { n group: } \\
\text { Mean } \\
121.7 \text { (SD } \\
10.7)\end{array}$ & $\begin{array}{l}\text { Unclear } \\
\text { risk }\end{array}$ \\
\hline
\end{tabular}




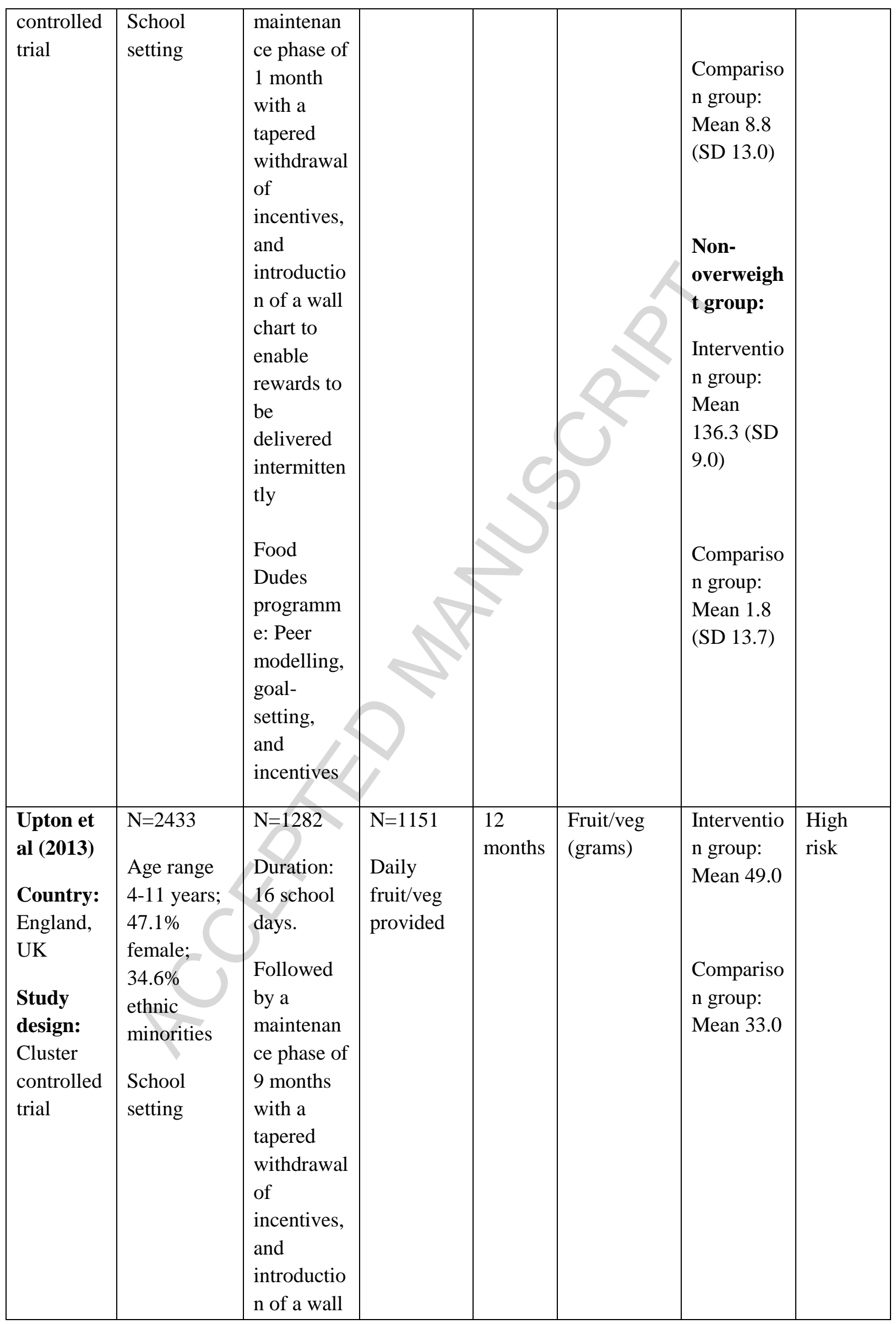




\begin{tabular}{|c|c|c|c|c|c|c|c|}
\hline & & $\begin{array}{l}\text { chart to } \\
\text { enable } \\
\text { rewards to } \\
\text { be } \\
\text { delivered } \\
\text { intermitten } \\
\text { tly } \\
\text { Food } \\
\text { Dudes } \\
\text { programm } \\
\text { e: Peer } \\
\text { modelling, } \\
\text { goal- } \\
\text { setting, } \\
\text { and } \\
\text { incentives }\end{array}$ & & & & & \\
\hline \multicolumn{8}{|c|}{ Target Behaviour: Smoking } \\
\hline $\begin{array}{l}\text { Crone et } \\
\text { al (2003) } \\
\text { Country: } \\
\text { The } \\
\text { Netherlan } \\
\text { ds } \\
\text { Study } \\
\text { design: } \\
\text { Randomis } \\
\text { ed cluster } \\
\text { controlled } \\
\text { trial }\end{array}$ & $\begin{array}{l}\mathrm{N}=2562 \\
\text { Mean age } \\
13 \text { years; } \\
44.8 \% \\
\text { female; } \\
83.9 \% \\
\text { Dutch } \\
\text { School } \\
\text { setting }\end{array}$ & $\begin{array}{l}\mathrm{N}=532 \\
\text { Duration: } \\
5 \text { months } \\
\text { Smoke } \\
\text { free class } \\
\text { competitio } \\
\mathrm{n} \\
\text { (admission } \\
\text { to a lottery } \\
\text { for prizes } \\
\text { if } 90 \% \\
\text { remain } \\
\text { abstinent) }\end{array}$ & $\begin{array}{l}\mathrm{N}=402 \\
\text { Usual } \\
\text { activities }\end{array}$ & $\begin{array}{l}20 \\
\text { months }\end{array}$ & $\begin{array}{l}\text { Self- } \\
\text { reported } \\
\text { current } \\
\text { smoking (\% } \\
\text { of } \\
\text { participants } \\
\text { who } \\
\text { smoked at } \\
\text { least } 1 \\
\text { cigarette a } \\
\text { week) }\end{array}$ & $\begin{array}{l}\text { Interventio } \\
\text { n group: } \\
133 / 532 \\
(25 \%) \\
\\
\text { Compariso } \\
\text { n group: } \\
117 / 402 \\
(29 \%)\end{array}$ & $\begin{array}{l}\text { Unclear } \\
\text { risk }\end{array}$ \\
\hline $\begin{array}{l}\text { Krishnan } \\
\text {-Sarin et } \\
\text { al (2006) } \\
\text { Country: } \\
\text { USA } \\
\text { Study } \\
\text { design: } \\
\text { Randomis } \\
\text { ed } \\
\text { controlled } \\
\text { trial }\end{array}$ & $\begin{array}{l}\mathrm{N}=28 \\
\text { Mean age } \\
17.5 \text { (SD } \\
1.8) ; 47.3 \\
\text { female; \% } \\
\text { ethnic } \\
\text { minorities } \\
\text { unavailable } \\
\text { School } \\
\text { setting }\end{array}$ & $\begin{array}{l}\mathrm{N}=17 \\
\text { Duration: } \\
4 \text { weeks } \\
\mathrm{CBT} \text {, and } \\
\text { financial } \\
\text { incentives } \\
\text { with a } \\
\text { reset } \\
\text { contingenc } \\
\text { y }\end{array}$ & $\begin{array}{l}\mathrm{N}=11 \\
\mathrm{CBT}\end{array}$ & $\begin{array}{l}4 \\
\text { weeks }\end{array}$ & $\begin{array}{l}\text { Objectively } \\
\text { measured } \\
\text { current } \\
\text { smoking (\% } \\
\text { assessed as } \\
\text { abstinent } \\
\text { from } \\
\text { smoking for } \\
7 \text { days } \\
\text { using self- } \\
\text { reports and } \\
\text { confirmed } \\
\text { using urine }\end{array}$ & $\begin{array}{l}\text { Interventio } \\
\text { n group: } \\
8 / 17 \\
(47 \%) \\
\\
\text { Compariso } \\
\text { n group: } \\
11 / 11 \\
(100 \%)\end{array}$ & $\begin{array}{l}\text { Unclear } \\
\text { risk }\end{array}$ \\
\hline
\end{tabular}




\begin{tabular}{|c|c|c|c|c|c|c|c|}
\hline & & & & & $\begin{array}{l}\text { cotinine } \\
\text { levels) }\end{array}$ & & \\
\hline $\begin{array}{l}\text { Krishnan } \\
\text {-Sarin et } \\
\text { al (2013) } \\
\text { Country: } \\
\text { USA } \\
\text { Study } \\
\text { design: } \\
\text { Randomis } \\
\text { ed } \\
\text { controlled } \\
\text { trial }\end{array}$ & $\begin{array}{l}\mathrm{N}=72 \\
\text { Mean age } \\
16.1 \text { (SD } \\
1.8) ; 53.7 \% \\
\text { female; \% } \\
\text { ethnic } \\
\text { minorities } \\
\text { unavailable } \\
\text { School } \\
\text { setting }\end{array}$ & $\begin{array}{l}\mathrm{N}=28 \\
\mathrm{CBT} \text {, and } \\
\text { financial } \\
\text { incentives } \\
\text { with a } \\
\text { reset } \\
\text { contingenc } \\
\mathrm{y} \\
\mathrm{N}=21 \text { Only } \\
\text { financial } \\
\text { incentives } \\
\text { with a } \\
\text { reset } \\
\text { contingenc } \\
\text { y } \\
\text { Duration: } \\
4 \text { weeks }\end{array}$ & $\begin{array}{l}\mathrm{N}=23 \\
\mathrm{CBT}\end{array}$ & $\begin{array}{l}16 \\
\text { weeks }\end{array}$ & $\begin{array}{l}\text { Objectively } \\
\text { measured } \\
\text { current } \\
\text { smoking (\% } \\
\text { assessed as } \\
\text { abstinent } \\
\text { from } \\
\text { smoking for } \\
7 \text { days } \\
\text { using self- } \\
\text { reports and } \\
\text { confirmed } \\
\text { using urine } \\
\text { cotinine } \\
\text { levels) }\end{array}$ & $\begin{array}{l}\text { Interventio } \\
\text { n group: } \\
45 / 49 \\
(92 \%) \\
\text { Compariso } \\
\text { n group: } \\
23 / 23 \\
(100 \%)\end{array}$ & $\begin{array}{l}\text { Unclear } \\
\text { risk }\end{array}$ \\
\hline $\begin{array}{l}\text { Isensee et } \\
\text { al (2012) } \\
\text { Country: } \\
\text { Germany } \\
\text { Study } \\
\text { design: } \\
\text { Randomis } \\
\text { ed cluster } \\
\text { controlled } \\
\text { trial }\end{array}$ & $\begin{array}{l}\mathrm{N}=3440 \\
\text { Mean age } \\
12.7 \text { (SD } \\
0.7) ; 50.5 \% \\
\text { female; } 96.3 \\
\text { German } \\
\text { School } \\
\text { setting }\end{array}$ & $\begin{array}{l}\mathrm{N}=757 \\
\text { Duration: } \\
6 \text { months } \\
\text { Smoke } \\
\text { free class } \\
\text { competitio } \\
\mathrm{n} \\
\text { (admission } \\
\text { to a lottery } \\
\text { for prizes } \\
\text { if } 90 \% \\
\text { remain } \\
\text { abstinent) }\end{array}$ & $\begin{array}{l}\mathrm{N}=604 \\
\text { Allocated } \\
\text { to } \\
\text { interventio } \\
\text { n group } \\
\text { but not } \\
\text { participati } \\
\text { ng } \\
\text { N=1059 } \\
\text { No } \\
\text { interventio } \\
n\end{array}$ & $\begin{array}{l}19 \\
\text { months }\end{array}$ & $\begin{array}{l}\text { Self- } \\
\text { reported } \\
\text { current } \\
\text { smoking (\% } \\
\text { self report } \\
\text { of "How } \\
\text { often they } \\
\text { smoked at } \\
\text { present") }\end{array}$ & $\begin{array}{l}\text { Interventio } \\
\text { n group: } \\
179 / 757 \\
(24 \%) \\
\text { Compariso } \\
\text { n group: } \\
467 / 1663 \\
(28 \%)\end{array}$ & $\begin{array}{l}\text { Low } \\
\text { risk }\end{array}$ \\
\hline $\begin{array}{l}\text { Reynolds } \\
\text { et al } \\
\text { (2015) } \\
\text { Country: } \\
\text { USA } \\
\text { Study } \\
\text { design: } \\
\text { Randomis } \\
\text { ed }\end{array}$ & $\begin{array}{l}\mathrm{N}=62 \\
\text { Mean age } \\
16.6 \text { (SD } \\
\text { 1.4); } 50 \% \\
\text { female; } \\
91.8 \% \\
\text { White } \\
\text { Home }\end{array}$ & $\begin{array}{l}\mathrm{N}=31 \\
\text { Duration: } \\
6 \text { weeks } \\
\text { Financial } \\
\text { incentives } \\
\text { (vouchers) } \\
\text { to be } \\
\text { redeemed } \\
\text { at specific }\end{array}$ & $\begin{array}{l}\mathrm{N}=31 \\
\text { Vouchers } \\
\text { for breath } \\
\text { samples } \\
\text { (not } \\
\text { contingent } \\
\text { on } \\
\text { abstinence } \\
\text { ) }\end{array}$ & $\begin{array}{l}12 \\
\text { weeks }\end{array}$ & $\begin{array}{l}\text { Objectively } \\
\text { measured } \\
\text { current } \\
\text { smoking } \\
\text { (Urinary } \\
\text { cotinine } \\
(\mathrm{ng} / \mathrm{ml}) \text { ) }\end{array}$ & $\begin{array}{l}\text { Interventi } \\
\text { on group: } \\
\text { Mean } \\
1080 \text { [SE } \\
146.7]\end{array}$ & $\begin{array}{l}\text { Low } \\
\text { risk }\end{array}$ \\
\hline
\end{tabular}




\begin{tabular}{|c|c|c|c|c|c|c|c|}
\hline $\begin{array}{l}\text { controlled } \\
\text { trial }\end{array}$ & setting & stores & & & & $\begin{array}{l}1280 \text { [SE } \\
146.7]\end{array}$ & \\
\hline $\begin{array}{l}\text { Schulze } \\
\text { et al } \\
(\mathbf{2 0 0 6 )} \\
\text { Country: } \\
\text { Germany } \\
\text { Study } \\
\text { design: } \\
\text { Randomis } \\
\text { ed cluster } \\
\text { controlled } \\
\text { trial }\end{array}$ & $\begin{array}{l}\mathrm{N}=4043 \\
\text { Mean age } \\
12.6 \text { (SD } \\
0.6 \text { ); 53.9\% } \\
\text { female; \% } \\
\text { ethnic } \\
\text { minorities } \\
\text { unavailable } \\
\text { School } \\
\text { setting }\end{array}$ & $\begin{array}{l}\mathrm{N}=948 \\
\text { Duration: } \\
6 \text { months } \\
\text { Smoke } \\
\text { free class } \\
\text { competitio } \\
\mathrm{n} \\
\text { (admission } \\
\text { to a lottery } \\
\text { for prizes } \\
\text { if } 90 \% \\
\text { remain } \\
\text { abstinent) }\end{array}$ & $\begin{array}{l}\mathrm{N}=756 \\
\text { Usual } \\
\text { activities }\end{array}$ & $\begin{array}{l}24 \\
\text { months }\end{array}$ & $\begin{array}{l}\text { Self- } \\
\text { reported } \\
\text { current } \\
\text { smoking (\% } \\
\text { self- } \\
\text { reporting } \\
\text { that they } \\
\text { currently } \\
\text { smoked) }\end{array}$ & $\begin{array}{l}\text { Interventio } \\
\text { n group: } \\
367 / 948 \\
(39 \%) \\
\end{array}$ & $\begin{array}{l}\text { Unclear } \\
\text { risk }\end{array}$ \\
\hline $\begin{array}{l}\text { Vartiaine } \\
\text { n et al } \\
\text { (1996) } \\
\text { Country: } \\
\text { Finland } \\
\text { Study } \\
\text { design: } \\
\text { Cluster } \\
\text { controlled } \\
\text { trial }\end{array}$ & $\begin{array}{l}\mathrm{N}=1835 \\
8^{\text {th }} \text { grade } \\
\text { pupils (14 } \\
\text { year olds); } \\
\% \text { female } \\
\text { unavailable; } \\
\% \text { ethnic } \\
\text { minorities } \\
\text { unavailable } \\
\text { School } \\
\text { setting }\end{array}$ & $\begin{array}{l}\text { N=976 } \\
\text { Duration: } \\
6 \text { months } \\
\text { Smoke } \\
\text { free class } \\
\text { competitio } \\
\mathrm{n} \\
\text { (admission } \\
\text { to a lottery } \\
\text { for prizes } \\
\text { if } 90 \% \\
\text { remain } \\
\text { abstinent) }\end{array}$ & $\begin{array}{l}\mathrm{N}=443 \\
\text { Usual }\end{array}$ & $\begin{array}{l}18 \\
\text { months }\end{array}$ & $\begin{array}{l}\text { Self- } \\
\text { reported } \\
\text { current } \\
\text { smoking (\% } \\
\text { self- } \\
\text { reporting } \\
\text { that they } \\
\text { currently } \\
\text { smoked) }\end{array}$ & $\begin{array}{l}\text { Interventio } \\
\text { n group: } \\
183 / 976 \\
(19 \%) \\
\\
\text { Compariso } \\
\text { n group: } \\
100 / 443 \\
(23 \%)\end{array}$ & $\begin{array}{l}\text { High } \\
\text { risk }\end{array}$ \\
\hline $\begin{array}{l}\text { Wiborg } \\
\text { et al } \\
(\mathbf{2 0 0 2}) \\
\text { Country: } \\
\text { Germany } \\
\text { Study } \\
\text { design: } \\
\text { Cluster } \\
\text { controlled } \\
\text { trial }\end{array}$ & $\begin{array}{l}\mathrm{N}=4372 \\
\text { Mean age } \\
12.9 \text { (SD } \\
1.0) ; 51.5 \% \\
\text { female; \% } \\
\text { ethnic } \\
\text { minorities } \\
\text { unavailable } \\
\text { School } \\
\text { setting }\end{array}$ & $\begin{array}{l}\mathrm{N}=1495 \\
\text { Duration: } \\
6 \text { months } \\
\text { Smoke } \\
\text { free class } \\
\text { competitio } \\
\mathrm{n} \\
\text { (admission } \\
\text { to a lottery } \\
\text { for prizes } \\
\text { if } 90 \% \\
\text { remain }\end{array}$ & $\begin{array}{l}\mathrm{N}=647 \\
\text { Usual } \\
\text { activities }\end{array}$ & $\begin{array}{l}12 \\
\text { months }\end{array}$ & $\begin{array}{l}\text { Self- } \\
\text { reported } \\
\text { current } \\
\text { smoking (\% } \\
\text { self- } \\
\text { reporting } \\
\text { that they } \\
\text { currently } \\
\text { smoked) }\end{array}$ & $\begin{array}{l}\text { Interventio } \\
\text { n group: } \\
127 / 1495 \\
(8 \%) \\
\end{array}$ & $\begin{array}{l}\text { High } \\
\text { risk }\end{array}$ \\
\hline
\end{tabular}




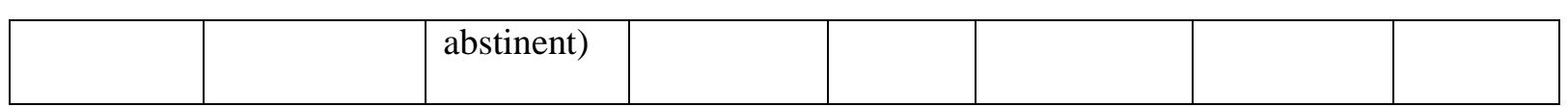




\section{Highlights}

- Results found strong evidence for behavioural incentives and healthier eating

- Results found some evidence for behavioural incentives and physical activity

- Results found limited evidence for behavioural incentives and smoking

- Results found no evidence for behavioural incentives and alcohol use 


\section{Std. Mean Difference}

Study or Subgroup

Brinker (2008)

Finkelstein et al (2013)

Goldfield et al (2006)

Hardman et al (2011)

Horne et al (2009a)

Roemmich et al (2004)

Roemmich et al (2012)

Suchert et al (2015)

\section{Total $(95 \% \mathrm{Cl})$}

Heterogeneity. $\mathrm{Tau}^{2}=0.60 ; \mathrm{Chi}^{2}=145.89, \mathrm{df}=7\left(\mathrm{P}<0.00001 \mathrm{j} ; \mathrm{I}^{2}=95 \%\right.$

Test for owerall effect: $Z=1.05(\mathrm{P}=0.29)$

$-0.16[-0.96,0.65]$

$1.76[1.45,2.07]$

$0.93[0.17,1.69]$

$-0.25[-0.51,0.00]$

$0.41[-0.01,0.83]$

$-0.19[-1.14,0.76]$

$0.03[-0.59,0.64]$

$-0.18[-0.29,-0.06]$

\section{$0.31[-0.27,0.88]$}

Std. Mean Difference

IV, Random, $95 \% \mathrm{CI}$

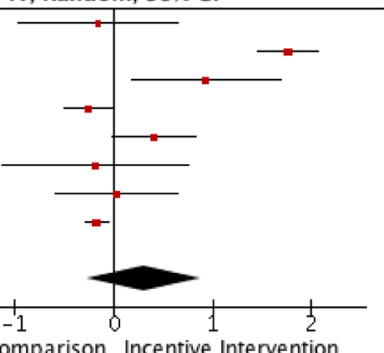

Figure 1 
Std. Mean Difference

Study or Subgroup

Brinker (2008)

Goldfield et al (2006)

Hardman et al (2011)

Horne et al (2009a)

Roemmich et al (2004)

Roemmich et al (2012)

Total $(95 \% \mathrm{Cl})$

Heterogeneity: Tau $^{2}=0.12 ; \mathrm{Chi}^{2}=13.36, \mathrm{df}=5(\mathrm{P}=0.02) ; \mathrm{I}^{2}=63 \%$

Test for overall effect: $Z=0.59(\mathrm{P}=0.56)$

$-0.16[-0.96,0.65]$

$0.93[0.17,1.69]$

$-0.25[-0.51,0.00]$

$0.41[-0.01,0.83]$

$-0.19[-1.14,0.76]$

$0.03[-0.59,0.64]$

$0.11[-0.26,0.48]$
Std. Mean Difference

IV, Random, $95 \% \mathrm{Cl}$

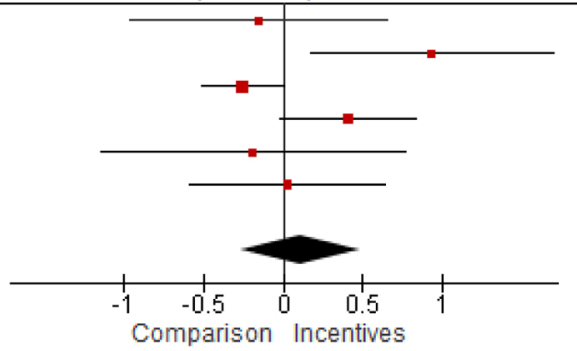

Figure 2 
Baranowski et al (2002)

$2.65[2.18,3.12]$

Horne et al (2009b)

$0.35[0.08,0.61]$

Morrill et al (2016)

$0.46[0.35,0.57]$

Total $(95 \% \mathrm{Cl})$

$1.12[0.19,2.05]$

Heterogeneity: Tau $^{2}=0.65 ; \mathrm{Chi}^{2}=81.75, \mathrm{df}=2(\mathrm{P}<0.00001) ; \mathrm{I}^{2}=98 \%$ Test for overall effect: $Z=2.36(P=0.02)$

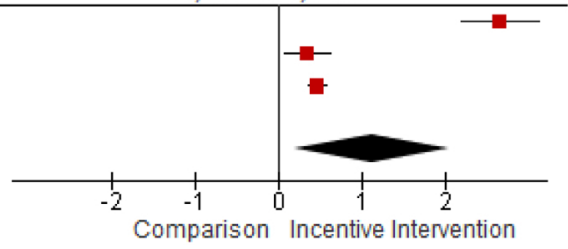

Figure 3 
Baranowski et al (2002)

Horne et al (2009b)

Morrill et al (2016)

Total $(95 \% \mathrm{Cl})$

Heterogeneity: $\mathrm{Tau}^{2}=0.00 ; \mathrm{Chi}^{2}=0.65, \mathrm{df}=1(\mathrm{P}=0.42) ; \mathrm{I}^{2}=0 \%$

Test for owerall effect: $Z=8.71(\mathrm{P}=0.00001)$

$0.35[0.08,0.61]$

$0.46[0.35,0.57]$

$0.45[0.35,0.55]$

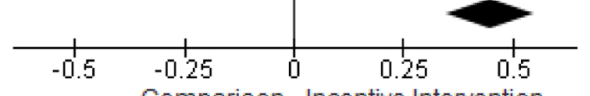

Comparison Incentive Intervention

Figure 4 


\subsubsection{Stop smoking competitions}

Crone et al (2003)

Isensee et al (2012)

$0.81[0.43,1.54]$

Schulze et al (2006)

$0.79[0.53,1.19]$

Vartiainen et al (1996)

$0.94[0.66,1.35]$

Wiborg et al (2002)

$0.79[0.44,1.44]$

Subtotal $(95 \% \mathrm{Cl})$

$0.63[0.33,1.21]$

$0.83[0.67,1.03]$

Heterogeneity: $\mathrm{Tau}^{2}=0.00 ; \mathrm{Chi}^{2}=1.27, \mathrm{df}=4(\mathrm{P}=0.87) ; \mathrm{I}^{2}=0 \%$

Test for overall effect: $Z=1.73(P=0.08)$

\subsubsection{Financial incentives}

Krishnan-Sarin et al (2006)

Krishnan-Sarin et al (2013)

Reynolds et al 2015

Subtotal $(95 \% \mathrm{Cl})$

$0.04[0.00,0.76]$

$0.22[0.01,4.17]$

$0.64[0.26,1.59]$

$0.29[0.06,1.42]$

Heterogeneity: Tau $^{2}=0.92 ; \mathrm{Chi}^{2}=3.41, \mathrm{df}=2(\mathrm{P}=0.18) ; \mathrm{I}^{2}=41 \%$

Test for overall effect: $Z=1.53(P=0.13)$

\section{Total $(95 \% \mathrm{Cl})$}

\section{$0.80[0.65,0.98]$}

Heterogeneity: $\mathrm{Tau}^{2}=0.00 ; \mathrm{Chi}^{2}=6.30, \mathrm{df}=7(\mathrm{P}=0.51) ; \mathrm{I}^{2}=0 \%$

Test for overall effect: $Z=2.12(\mathrm{P}=0.03)$

Test for subqroup differences: $\mathrm{Chi}^{2}=1.65, \mathrm{df}=1(\mathrm{P}=0.20), \mathrm{I}^{\mathrm{z}}=39.4 \%$

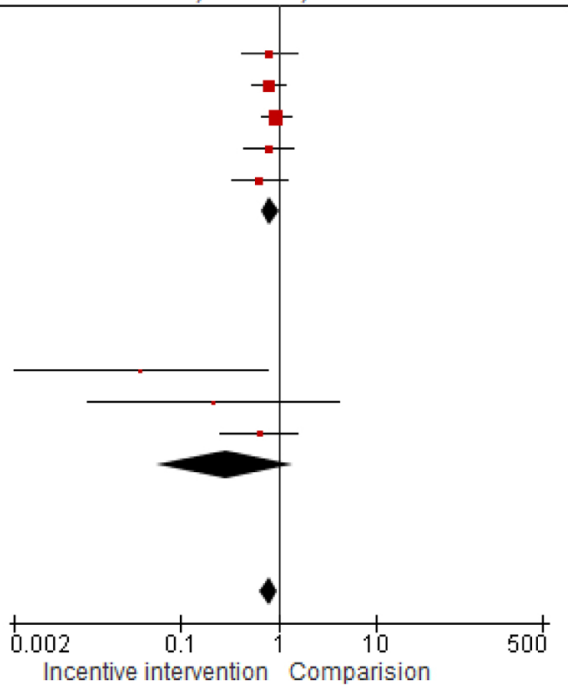

Figure 5 


\section{Number of BCTs}

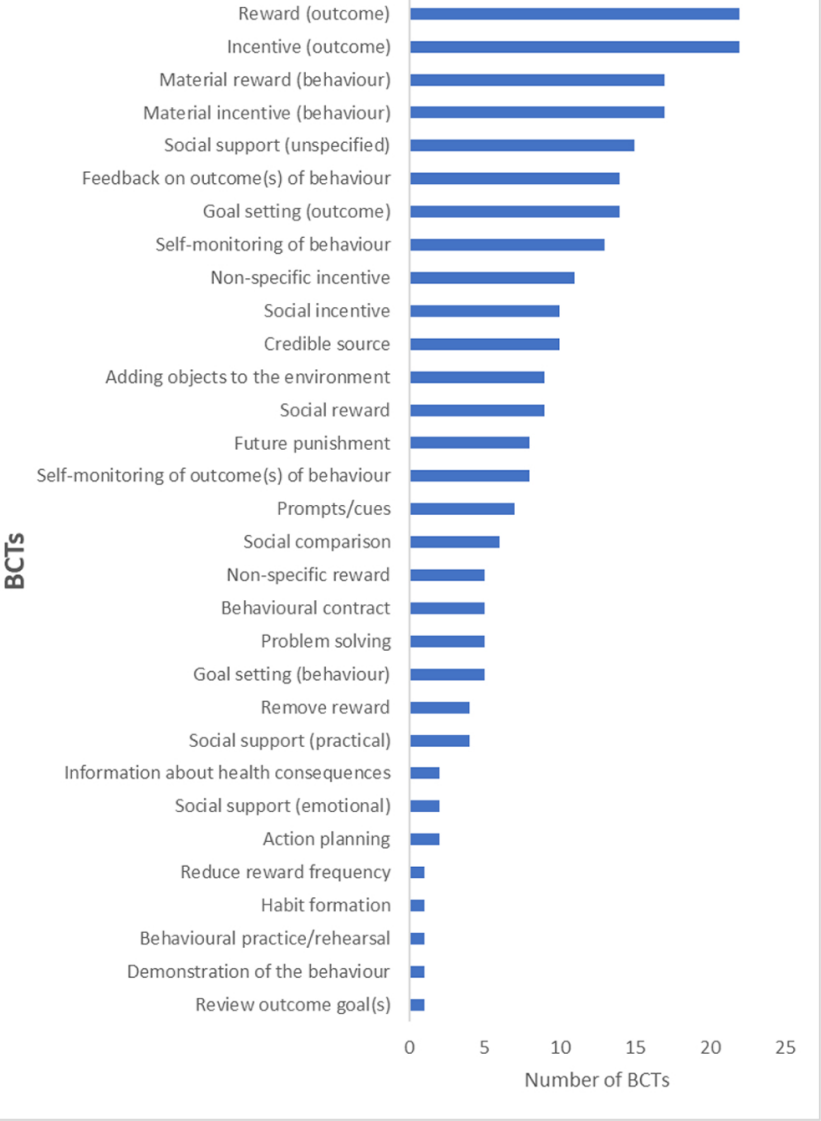

Figure 6 